\title{
Pinochet and International Human Rights Litigation
}

\section{Citation}

Jack L. Goldsmith and Curtis A. Bradley, Pinochet and International Human Rights Litigation, 97 Michigan Law Review 2129

\section{Permanent link}

http://nrs.harvard.edu/urn-3:HUL.InstRepos:3425951

\section{Terms of Use}

This article was downloaded from Harvard University's DASH repository, and is made available under the terms and conditions applicable to Other Posted Material, as set forth at http:// nrs.harvard.edu/urn-3:HUL.InstRepos:dash.current.terms-of-use\#LAA

\section{Share Your Story}

The Harvard community has made this article openly available.

Please share how this access benefits you. Submit a story.

Accessibility 


\section{HEINONLINE}

Citation: 97 Mich. L. Rev. 2129 1998-1999

Content downloaded/printed from

HeinOnline (http://heinonline.org)

Mon Nov 30 13:33:11 2009

-- Your use of this HeinOnline PDF indicates your acceptance of HeinOnline's Terms and Conditions of the license agreement available at http://heinonline.org/HOL/License

-- The search text of this PDF is generated from uncorrected OCR text.

-- To obtain permission to use this article beyond the scope of your HeinOnline license, please use:

https://www.copyright.com/ccc/basicSearch.do?

\&operation $=$ go\&search Type $=0$

\&lastSearch $=$ simple\&all $=$ on\&titleOrStdNo $=0026-2234$ 


\title{
PINOCHET AND INTERNATIONAL HUMAN RIGHTS LITIGATION
}

\author{
Curtis A. Bradley* \\ Jack L. Goldsmith**
}

TABLE OF CONTENTS

I. InTRODUCTION........................... 2130

II. The PInochet CAse ....................... 2132

A. Background and Proceedings .............. 2133

B. International Law Uncertainties .............. 2140

III. PINochet ANd the International Law

OverRide Strategy ...................... 2146

A. Potential Relevance of Pinochet to U.S.

Litigation ............................ 2147

B. U.S. Rejection of the International Law

Override Strategy ......................... 2151

C. Back to Pinochet......................... 2158

IV. Head-of-State Immunity AND the Domestic Status of Customary INTERNATIONAL LAW .... 2159

A. Head-of-State Immunity and Erie ........... 2161

B. Modern Practice ......................... 2165

C. Significance for Human Rights Litigation in U.S. Courts ............................... 2167

V. Why RESIST the DOMESTIC INCORPORATION OF INTERNATIONAL HuMAN RigHTS LAW? ..........

A. Domestic Officials ...................... 2173

B. Foreign Officials ...................... 2180

VI. Conclusion ................................ 2183

* Visiting Associate Professor, University of Virginia School of Law and Associate Professor, University of Colorado School of Law. B.A. 1985, University of Colorado; J.D. 1988, Harvard. - Ed.

** Professor, University of Chicago Law School. B.A. 1984, Washington \& Lee; B.A. 1986, Oxford; J.D. 1989, Yale. - Ed. For helpful comments and suggestions, we thank Paul Campos, David Fidler, Elizabeth Garrett, Jill Hasday, David Martin, Hiroshi Motomura, Dale Oesterle, Eric Posner, David Strauss, Cass Sunstein, Adrian Vermeule, Phil Weiser, and Ted White. We also thank John Bies, Natalie Mack, Steve Putnam, and David Wadsworth for their excellent research assistance, and Lyonette Louis-Jacques and Jane Thompson for their extraordinary assistance in locating resources. Professor Goldsmith would also like to thank the Arnold and Frieda Shure Research Fund for support. 


\section{INTRODUCTION}

The British House of Lords recently considered whether Augusto Pinochet was subject to arrest and possible extradition to Spain for alleged acts of torture and other egregious conduct carried out during his reign as Chile's head of state. ${ }^{1}$ The Law Lords held that a large majority of the charges against Pinochet were not proper grounds for extradition under British law. They also held, however, that Pinochet could potentially be extradited for alleged acts of torture committed after Britain's 1988 ratification of the Convention Against Torture and Other Cruel, Inhuman or Degrading Treatment or Punishment. ${ }^{2}$ In reaching this latter conclusion, a majority of the Law Lords rejected Pinochet's claim that he was entitled to immunity from arrest on the torture charges because of his status as a former head of state.

The Pinochet decision implicates a number of difficult issues at the heart of modern international law. It illustrates the growing tension between the international law principle of sovereign equality and the quest for universal justice. It raises the question of whether international criminal law should be enforced unilaterally by national courts or through multilateral international tribunals. And it highlights the more fundamental issue of whether any international criminal process is appropriate when a nation, like Chile, has addressed the human rights abuses of a prior regime through a domestic political compromise that facilitated a transition to democracy.

Although these international law issues are relevant to this article, they are not its focus. The article focuses instead on a related issue also implicated in Pinochet: international law's increasing interaction with and influence on domestic law and processes. In particular, we consider what, if anything, can be learned from Pinochet regarding the relationship between international law and U.S. domestic law. The specific circumstances of the Pinochet case - criminal extradition proceedings against a former head of state

1. See Regina v. Bow Street Magistrate, Ex parte Pinochet, [1999] 2 W.L.R. 827 (H.L.) [hereinafter Second Law Lords' Decision]. Judicial appeals to the House of Lords are heard by the Lords of Appeal in Ordinary, or "Law Lords." Most appeals are heard by five Law Lords, but cases considered especially important are sometimes heard by seven. The Law Lords act as the final court of appeal for all civil cases in Great Britain and for all criminal cases in England, Wales, and Northern Ireland. See Fiona Cownie \& ANTHONY BradNEY, English Legal System in Context 41-45 (1996); Gary Slapper \& David Kelly, PrinCIPLES OF THE ENGLISH LEGAL SYSTEM 61-62 (1997).

2. Convention Against Torture and Other Cruel, Inhuman or Degrading Treatment or Punishment, opened for signature Feb. 4, 1985, S. TREATY Doc. No. 100-20 (1988), 1465 U.N.T.S. 85 [hereinafter Torture Convention]. 
- will not arise often in the United States. For the past two decades, however, U.S. courts have been grappling with issues similar to those presented in Pinochet in numerous civil suits alleging violations of international human rights law by foreign officials. The parties and judges in the Pinochet case extensively considered this U.S. case law in analyzing whether Pinochet was entitled to immunity. In this article, we in effect do the opposite: we assess how the Pinochet decision and its international law holdings might be relevant to U.S. civil litigation.

Plaintiffs and commentators are likely to claim that the Law Lords' analysis in Pinochet - especially their reliance on international human rights law to limit Pinochet's immunity - supports application of international human rights law by U.S. courts in civil litigation. The bulk of this article is devoted to showing why this is not so. Because of structural differences between the criminal and civil contexts, as well as differences between the British and U.S. approaches to the incorporation of international law, we conclude that Pinochet provides little support for civil human rights litigation against foreign officials in U.S. courts. We also argue that, because of the vagueness of international human rights law and the adverse foreign relations implications of civil suits against foreign officials, human rights litigation in U.S. courts should remain both limited in scope and under the control of the federal political branches. Not only is there nothing in the Pinochet decision to the contrary, but in several ways it bolsters our conclusions.

We begin in Part II by describing the background and proceedings of the Pinochet case, the House of Lords' analysis, and the international law uncertainties highlighted by the Law Lords' decision. In Part III, we consider whether developments in international human rights law should limit the scope of the domestic immunity available to foreign governments and officials. The Law Lords held that these developments did limit the scope of Pinochet's immunity from criminal process in Great Britain. In the United States, however, the political branches and the federal courts have, with narrow and specific exceptions, declined to permit developments in international human rights law to limit the scope of foreign sovereign immunity from civil process. We argue that the adverse political consequences that might flow from otherwise unfettered private lawsuits against foreign officials for human rights abuses justify the broader immunities available in U.S. domestic courts. 
In Part IV, we consider the legitimacy of the U.S. counterpart to the British rule, invoked by some of the Law Lords in Pinochet, that customary international law (CIL) is part of the British common law. In the United States, plaintiffs and scholars have argued for a similar rule of incorporation to justify the domestic application of substantive international human rights law. As we explain, however, the constitutional implications of an automatically incorporated CIL are more problematic for the United States than they are for Great Britain. As a result, when faced with claims of international immunity, such as the claim of head-of-state immunity that was at issue in Pinochet, U.S. courts do not apply the CIL governing this immunity directly. Instead, they seek and follow politicalbranch direction. The failure by courts to apply CIL as automatically incorporated common law in this context, involving traditional rules of CIL that are a central component of international relations, casts substantial doubt on the claim that international human rights law should be applied as self-executing federal common law.

In Part V, we defend the United States' general resistance to the domestic application of international human rights law. This resistance has two dimensions. First, the United States does not apply international human rights law to domestic officials. This approach is justified by the profound uncertainty regarding the source and content of international law and by the general adequacy of U.S. domestic human rights protections. Second, the United States permits the domestic application of international human rights law against foreign governmental officials only in very narrow contexts. This limited embrace of international human rights law reflects a legitimate concern with giving private citizens, and unelected judges, too much influence over U.S. foreign relations. As we explain, both of these justifications for resistance to the domestic application of international human rights law - the vagueness of international norms and the danger that private lawsuits will interfere with foreign relations - find support in the House of Lords' decision in Pinochet.

\section{The Pinochet CASE}

In this Part, we analyze the Pinochet case. We begin by explaining the background of the case and the complex proceedings leading up to the House of Lords' decision. We then discuss some of the many legal uncertainties highlighted by the decision. 


\section{A. Background and Proceedings ${ }^{3}$}

Pinochet's Reign and Status. In 1973, Pinochet, then the commander in chief of the army in Chile, led a military coup that overturned the elected government of President Salvador Allende. A military junta subsequently appointed Pinochet president of Chile, and he ruled the country for the next seventeen years. During his rule, hundreds of thousands of people were detained for political reasons, and several thousand disappeared or were killed. Pinochet stepped down as president in 1990 , but he remained head of the army until March 1998, when he was appointed "Senator for Life."

Pinochet's Arrest. On September 22, 1998, at the age of 82, Pinochet entered the United Kingdom for back surgery. On October 16, British authorities arrested him while he was recovering from the surgery in a London hospital. They based the arrest on a provisional warrant issued by a British magistrate, which was in turn based on an international arrest warrant issued by a judge in Spain. ${ }^{4}$ The international warrant alleged that Pinochet was responsible for murdering Spanish citizens in Chile between 1973 and 1983 and that Spain intended to seek his extradition. On October 22 , a British magistrate issued a second provisional warrant based on a new international warrant from the Spanish judge alleging that Pinochet was responsible for acts of torture, hostage taking, and other conduct committed primarily, although not exclusively, against Chilean citizens in Chile. To understand the legal context of these warrants and the subsequent proceedings, it is necessary to consider briefly the international law concept of "universal jurisdiction," as well as British law concerning extradition and immunity.

Universal Jurisdiction. International law normally requires that a nation that regulates conduct outside its territory have some connection with the conduct or the person engaged in the conduct. International law also recognizes, however, the concept of "universal jurisdiction," pursuant to which certain categories of conduct can be regulated by any nation. 5 The theory is that those who engage in this conduct are hostis humani generis, or "enemies of all mankind,"

3. Unless otherwise specified, the facts in this section are drawn from the various opinions in the case.

4. For a description of how the proceedings against Pinochet were initiated in Spain, see Richard J. Wilson, Prosecuting Pinochet in Spain, 6 Hum. RTs. Br. 3 (1999).

5. See generally Restatement (ThiRD) of the Foreign Relations LAW of THE UNITED STATES $\$ 404$ (1987); Kenneth C. Randall, Universal Jurisdiction Under International Law, 66 TEXAs L. REv. 785 (1988) [hereinafter Universal Jurisdiction]. 
and that all nations therefore have an interest in punishing them. ${ }^{6}$ In the nineteenth century, nations invoked this concept to justify regulation of piracy on the high seas and, in some instances, the slave trade. ${ }^{7}$ After World War II, national courts and international war tribunals asserted universal jurisdiction over war crimes and crimes against humanity. ${ }^{8}$ Modern treaties appear to authorize universal jurisdiction over certain additional crimes, such as torture, hostage taking, and hijacking. ${ }^{9}$

The universal jurisdiction concept was relevant to the Pinochet case in several ways. First, Spain invoked this concept as a basis for regulating, and requesting extradition for, Pinochet's alleged conduct. The torture, hostage taking, and other acts allegedly committed by Pinochet took place primarily in Chile. Moreover, most of the victims were not Spanish citizens, and Pinochet was not himself a Spanish citizen. Nevertheless, the universal jurisdiction concept allowed Spain to claim authority under international law to regulate Pinochet's conduct. Second, this concept played an important role in the House of Lords' application of British extradition law. Historically, torture was not an extraterritorial crime in Britain. In 1988, however, Britain enacted a criminal statute authorizing universal jurisdiction over official acts of torture committed anywhere in the world. ${ }^{10}$ As explained below, the House of Lords ultimately found that acts of torture committed by Pinochet before the enactment of this statute were not a proper basis for extradition. Finally, some of the Law Lords invoked the universal jurisdiction concept as a justification for limiting Pinochet's head-of-state immunity.

6. See Kenneth C. Randall, Federal Questions and the Human Rights Paradigm, 73 MinN. L. Rev. 349, 416-17 (1988) [hereinafter Federal Questions]; see also Filartiga v. Pena-Irala, 630 F.2d 876, 890 (2d Cir. 1980) ("[F]or purposes of civil liability, the torturer has become like the pirate and slave trader before him - hostis humani generis, an enemy of all mankind.").

7. See Jeffrey M. Blum \& Ralph G. Steinhardt, Federal Jurisdiction over International Human Rights Claims: The Alien Tort Claims Act after Filartiga v. Pena-Irala, 22 Harv. INTL. L.J. 53, 60-62 (1981). But cf. AlFred P. RuBIN, ETHICS ANd AUTHORITY IN INTERNA. TIONAL LAW 84-110 (1997) (arguing that the nineteenth century piracy and slave trade cases all involved connections to the regulating state).

8. See Randall, Universal Jurisdiction, supra note 5, at 805-10. The universal jurisdiction concept was invoked by Israel, for example, as a basis for trying Adolf Eichmann after it abducted him from Argentina. See Cr.A. 333/61, Attorney Gen. of Isr. v. Eichmann, 16 P.D. 2033, 2047, 2060-67, 36 I.L.R. 5, 287, 298-304 (S. Ct. 1962) (Isr.).

9. See Randall, Universal Jurisdiction, supra note 5, at 816-19.

10. See Criminal Justice Act, 1988 , ch. $33, \S 134$, reprinted in 12 Halsbury's Statutes of ENGLAND AND Wales 1079 (4th ed. 1997). 
Britain's Extradition Statute. Extradition in Great Britain is governed by its 1989 Extradition Act.11 This Act provides that a person who is in Great Britain and is accused in a foreign state of an "extradition crime" may be "arrested and returned" to that state if the state has an extradition treaty with Great Britain. ${ }^{12}$ The Act defines an extradition crime as either an offense committed within the territory of the foreign state or an extraterritorial offense against the law of the foreign state. ${ }^{13}$ For extraterritorial offenses, however, either the foreign state must base its jurisdiction on the nationality of the offender, or the crime charged must be such that "in corresponding circumstances equivalent conduct would constitute an extra-territorial offence against the law of the United Kingdom."14 In extradition parlance, this is a form of "double criminality" requirement. ${ }^{15}$ The Act also makes clear that extradition proceedings cannot be carried out without the approval of Britain's Home Secretary. ${ }^{16}$ The Act does allow, however, for an initial arrest and preliminary proceedings based, as in the Pinochet case, on the issuance of a "provisional warrant."17

Britain's Immunity Law. Great Britain has a statute regulating foreign governmental immunity in its courts. ${ }^{18}$ This statute specifically includes heads of state in its list of entities entitled to sovereign immunity in civil litigation. ${ }^{19}$ Of more relevance to the Pinochet case, the statute also provides that, "subject to . . . any necessary modifications," heads of state shall be entitled to the immunities accorded to diplomats. ${ }^{20}$ Britain's diplomatic immunity statute, in turn, accords diplomats absolute criminal immunity while

11. See Extradition Act, 1989, ch. 33, reprinted in 17 HaLSBURY's STATUTES OF ENGLAND AND WALES 558 (4th ed. 1993).

12. Extradition Act $\S 1(1)$. The pertinent international extradition agreement between the United Kingdom and Spain is the European Convention on Extradition, Dec. 13, 1957, U.K.-Spain, 359 U.N.T.S. 273.

13. See Extradition Act $\S 2(1)$.

14. Extradition Act $\S 2(2)$.

15. For an introduction to the concept of double criminality, see M. CHERIF BAsSIOUN, International Extradition: United States Law and Practice 388-93 (3d ed. 1996).

16. See Extradition Act $\S 7(1)$. The Act refers generally to the "Secretary of State." There are a number of secretaries of state in Great Britain, each with different responsibilities. Responsibilities relating to extradition have been assigned to the Home Secretary. See Hilaire Barnett, Constitutional and Administrative Law 786-87 (2d ed. 1998).

17. See Extradition Act $\S 8(1)$ (b). A provisional warrant may be issued prior to the receipt of an authorization by the Home Secretary to proceed with extradition. See \$ 8(1)(b). The Home Secretary has the power to cancel such a warrant, and he must do so if he decides not to issue an authorization to proceed. See $\$ 8(4)$.

18. See State Immunity Act, 1978, ch. 33 (Eng.), reprinted in 17 I.L.M. 1123.

19. See State Immunity Act $\S 14(1)(a)$.

20. See State Immunity Act $\S 20(1)$. 
they are serving as part of a diplomatic mission. ${ }^{21}$ This form of immunity, known as immunity "ratione personae," is a status immunity that attaches to diplomats - and, by reference, to heads of state as the personal embodiment of the foreign state during their time in service. After their service ceases, diplomats - and, by reference, heads of state - are then entitled to criminal immunity for the acts they performed while carrying out their official functions. ${ }^{22}$ This form of immunity, known as immunity "ratione materiae," is a subject matter immunity that prevents the official acts of one state from being called into question in the courts of another. ${ }^{23}$

Divisional Court Decision. Pinochet challenged his arrest in court and, on October 28, a three-judge panel of the Divisional Court of the Queen's Bench Division of the High Court of Justice held both provisional arrest warrants invalid. ${ }^{24}$ The court held that the first warrant failed to comply with the double criminality requirement because British law would not allow for jurisdiction over the murder of a British citizen committed abroad. The court further held that both warrants were invalid because, as a former head of state, Pinochet was entitled to immunity from arrest. The court acknowledged that Pinochet's alleged acts were criminal under international law but noted that "[a] former head of state is clearly entitled to immunity in relation to criminal acts performed in the course of exercising public functions." 25 Britain's Crown Prosecution Service appealed the decision on behalf of Spain, and several human rights groups, including Amnesty International, intervened in the appeal. In the meantime, Spain issued a formal extradition request that substantially expanded the number and description of crimes allegedly committed by Pinochet, adding, among other things, a charge of genocide.

First Law Lords' Decision. On November 25, a five-member panel of the House of Lords overturned the Divisional Court's ruling. ${ }^{26}$ As is customary, the decision took the form of seriatim opinions. The Law Lords held, by a 3-2 majority, that Pinochet was not

21. See Diplomatic Privileges Act, 1964, ch. 81, sched. 1, art. 29, reprinted in 10 HalsburY's STATUTES OF ENGLAND AND WALES 676, 682 (4th ed. 1995).

22. See Diplomatic Privileges Act $\$ 39$.

23. For a general discussion of the distinction between immunity ratione personae and immunity ratione materiae, see IAN Brownlie, PrInCIPLES of PUBlic InTERnational Law 330-31 (4th ed. 1990).

24. See In re an Application for a Writ of Habeas Corpus ad Subjiciendum re: Augusto Pinochet Ugarte, 38 I.L.M. 68 (Q.B. Divl. Ct. 1998) [hereinafter Divisional Court Decision].

25. Divisional Court Decision, 38 I.L.M. at 83 (Lord Bingham).

26. See Regina v. Bartle, Ex parte Pinochet, [1998] 3 W.L.R. 1456 (H.L.) [hereinafter First Law Lords' Decision]. 
entitled to immunity for the acts alleged in the second arrest warrant. They reasoned that the immunity of former heads of state does not apply to acts of torture and hostage taking because such acts do not constitute official functions of a head of state under international law. ${ }^{27}$ As one member of the majority explained,

international law has made plain that certain types of conduct, including torture and hostage-taking, are not acceptable conduct on the part of anyone. This applies as much to heads of state, or even more so, as it does to everyone else; the contrary conclusion would make a mockery of international law. ${ }^{28}$

The dissenters argued, by contrast, that head-of-state immunity applies to illegal acts and has not been abrogated by relevant treaties or custom. ${ }^{29}$

In early December, Britain's Home Secretary authorized the extradition proceedings to go forward, except with respect to the charge of genocide. ${ }^{30}$ Shortly thereafter, Pinochet's lawyers petitioned the House of Lords to vacate the panel decision because one member of the majority had failed to disclose that he was an unpaid director of a fund-raising arm of Amnesty International. On December 17, the House of Lords, in an unprecedented step, granted the request and vacated the decision. ${ }^{31}$

Second Law Lords' Decision. A seven-member panel of the House of Lords reheard the appeal in January and early February 1999. The government of Chile intervened in these proceedings and argued for Pinochet's release. During the proceedings, Britain's Crown Prosecutor submitted a schedule stating that Spain's allegations against Pinochet - with the exception of the genocide charge - would constitute thirty-two violations of British criminal law. On March 24, 1999, after seven weeks of deliberation, the House of Lords issued its second decision.

The second decision differed significantly from the first. It did not reach the head-of-state immunity issue until after it had first dismissed, on the basis of double criminality, a large majority of the extradition charges against Pinochet. As noted above, the British

27. See First Law Lords' Decision, [1998] 3 W.L.R. at 1499-1502 (Lord Nicholls), 1506 (Lord Steyn), 1508 (Lord Hoffman).

28. [1998] 3 W.L.R. at 1500 (Lord Nicholls).

29. See [1998] 3 W.L.R. at 1476-78 (Lord Slynn), 1492-93 (Lord Lloyd).

30. See 38 I.L.M. 489 (1999) (statement of Jack Straw, Home Secretary). The Home Secretary did not authorize extradition proceedings on the genocide charge because he concluded that the double criminality requirement was not satisfied with respect to that charge. See id.

31. See In re Pinochet, [1999] 2 W.L.R. 272 (H.L.) (oral judgment delivered on December $17,1998$, written reasons on January 15,1999$)$. 
extradition statute allows extradition for extraterritorial offenses if "in corresponding circumstances equivalent conduct would constitute an extraterritorial offense against the law of the United Kingdom."32 The Divisional Court had concluded with little analysis that this requirement meant simply that the conduct must be a crime under British law at the time of the extradition request. ${ }^{33}$ The first House of Lords' decision appeared to reach the same conclusion on this point, again with little analysis. ${ }^{34}$ In the second decision, by contrast, the Law Lords considered the issue in detail. ${ }^{35}$ They held unanimously that the extradition statute requires the extraterritorial conduct to have been a crime under British law at the time the conduct took place. Most of the charges against Pinochet, including most of the charges regarding torture, concerned conduct prior to September 29,1988, the date when Great Britain made torture an extraterritorial crime. Six of the seven Law Lords concluded that these charges therefore could not serve as a basis for extradition. ${ }^{36}$

After reaching this conclusion regarding double criminality, and after dismissing the hostage-taking charge on the merits, ${ }^{37}$ the Law Lords were left with charges relating to torture and conspiracy to commit torture after September 29, 1988, and with charges of conspiracy in Spain to commit murder and torture in Spain. It was with respect to these charges that the Law Lords considered the issue of immunity. Six of the Law Lords agreed that Pinochet was generally

32. Extradition Act, 1989, ch. 33, §2(2), reprinted in 17 HalsBuRy's StatuTES of ENGLAND AND WaLes 558, 561 (4th ed. 1993).

33. See Divisional Court Decision, 38 I.L.M. 68, 79 (Q.B. Divl. Ct. 1998) (Lord Bingham) ("[T]he conduct alleged against the subject of the request need not in my judgment have been criminal here at the time the alleged crime was committed abroad."). The Home Secretary relied on this holding in his statement authorizing extradition proceedings to go forward.

34. See First Law Lords' Decision, [1998] 3 W.L.R. at 1481 (Lord Lloyd) (noting that he "agree[d] with the Divisional Court that [the argument that the conduct must have been criminal in Great Britain when it occurred] is bad").

35. Apparently, Pinochet's lawyers revived this argument during the second House of Lords' hearing in response to the Crown Prosecution Service's attempt to extend the charges against Pinochet to include conduct allegedly committed before Pinochet was head of state. See Second Law Lords' Decision, [1999] 2 W.L.R. 827, 833 (H.L.) (Lord Browne-Wilkinson).

36. Lord Millett dissented on this point, reasoning that extraterritorial torture was a common law crime in Britain before the Convention came into force, and thus satisfied the double criminality requirement. See Second Law Lords' Decision, [1999] 2 W.L.R. at 912 (Lord Millett). The Law Lords also dismissed the non-torture charges on double criminality grounds; the complex reasons for the dismissal are set forth in Lord Hope's opinion. See [1999] 2 W.L.R. at 870-71 (Lord Hope).

37. The Law Lords concluded that the charges against Pinochet relating to hostage taking failed to state a claim under Britain's 1982 Hostage Taking Act because there was no allegation that the hostage taking was designed to compel action or inaction by third parties. See [1999] 2 W.L.R. at 840 (Lord Browne-Wilkinson), 850 (Lord Goff), 871 (Lord Hope). 
entitled to immunity under both British statutory law and international law for criminal conduct committed while carrying out his functions as head of state. ${ }^{38}$ Six of the Law Lords also concluded, however, that this former-head-of-state immunity did not cover acts of torture and conspiracy to commit torture committed after December 8, 1988, the date Britain ratified the Torture Convention. This is the most important holding in the case. Lord Goff dissented from this holding, arguing that Pinochet was entitled to immunity even for post-1988 acts of torture because neither the Torture Convention nor CIL abrogated former-head-of-state immunity. ${ }^{39}$

Three features of the Law Lords' decision have special relevance to this article. First, several of the Law Lords who embraced the head-of-state immunity holding drew a distinction between immunity in a criminal proceeding and immunity in civil litigation. ${ }^{40}$ They acknowledged and appeared to agree with case authority, especially U.S. case authority, supporting immunity in civil litigation for torture and other egregious acts. Second, the Law Lords looked to $\mathrm{CIL}$ to interpret the scope of British immunity law, in part because they concluded that British statutory law refers to CIL principles, but also because of the long-standing British rule that CIL is incorporated as part of the common law. Finally, six of the Law Lords expressed the view that the Home Secretary should reconsider his authorization of the extradition proceedings in light of the substantial reduction in the scope of the charges resulting from the Law Lords' decision. ${ }^{41}$

New Authorization to Proceed. On April 14, the Home Secretary issued a second authorization allowing the extradition proceedings against Pinochet to go forward. The Home Secretary concluded, among other things, that the House of Lords' reduction of the extradition charges against Pinochet did not warrant dismissal of the case. ${ }^{42}$ He noted that he had wide discretion in deciding whether to authorize extradition proceedings and that he had taken

38. Lord Phillips dissented on this point, reasoning that the immunity statute gave Pinochet immunity only for acts committed in Great Britain. See [1999] 2 W.L.R. at 927 (Lord Phillips).

39. See [1999] 2 W.L.R. at 862 (Lord Goff).

40. See [1999] 2 W.L.R. at 889 (Lord Hutton), 913 (Lord Millett), 921 (Lord Phillips).

41. Several of the Law Lords also noted that if the Home Secretary did permit the proceedings to continue, the magistrate presiding over the extradition proceedings should carefully review the evidence concerning the remaining alleged crimes to ensure that these crimes satisfied the double criminality requirement.

42. See 329 PARL. DeB., H.C. (Hansard) 311, 315 (1998) (statement of Jack Straw, Home Secretary). 
a range of factors into consideration. ${ }^{43}$ In addition to assessing the legal grounds for extradition, the Home Secretary considered a number of nonlegal factors, including "the possible effect of extradition proceedings on the stability of Chile, and its future democracy; and ... the possible effect of extradition proceedings on the UK national interest." 44 As of this writing, Pinochet remains under house arrest in England, and extradition proceedings are scheduled to begin in late September, 1999.

\section{B. International Law Uncertainties}

In the Pinochet case, three different judicial panels examined the immunity issue, and each panel adopted a different approach. Moreover, although most of the Law Lords in the latest decision agreed that Pinochet was not entitled to immunity for acts of torture committed after December 8, 1988, their reasoning in support of this conclusion is unclear and often contradictory. In this section, we analyze the Law Lords' justifications for denying Pinochet immunity. Our analysis is not intended as an argument against the House of Lords' ultimate holding. Instead, our aim is to illustrate how open-ended and uncertain the law is in this area.

A majority of the Law Lords suggested that a former head of state like Pinochet traditionally would have been entitled to immunity for acts of torture under international law. ${ }^{45}$ Most of the Law Lords also agreed that something happened in or by 1988 to limit this immunity. No clear answer emerges from the Law Lords' opinions, however, as to how or why this limitation came about. ${ }^{46}$

A head of state's government holds the right to the head-ofstate immunity, and may therefore waive it. ${ }^{47}$ One possible basis for the limitation of immunity, therefore, is that Chile waived immunity in 1988 when it ratified the Torture Convention. Any such waiver, however, must have been implicit, since the Convention

43. Id. at 315.

44. Id. at 316.

45. See Second Law Lords' Decision, [1999] 2 W.L.R. at 847 (Lord Browne-Wilkinson), 855 (Lord Goff), 886 (Lord Hope), 903 (Lord Saville).

46. Lord Phillips was the only Law Lord to deny the premise that former heads of state had a traditional immunity from criminal process under international law. He reasoned that, because national jurisdiction over universal crimes was a recent and rare phenomenon, there was in fact no CIL practice of granting former heads of state immunity from criminal process. See [1999] 2 W.L.R. at 918 (Lord Phillips).

47. See [1999] 2 W.L.R. at 902 (Lord Saville), 906 (Lord Millett), 924 (Lord Phillips); see also BrowNLIE, supra note 23, at 340. For U.S. decisions to this effect, see, e.g., In Re Doe, 860 F.2d 40, 45 (2d Cir. 1988) and In Re Grand Jury Proceedings, 817 F.2d 1108, 1110 (4th Cir. 1987). 
does not mention immunity. As several Law Lords pointed out, implicit waivers of immunity are disfavored under international law. 48 Perhaps for this reason, a number of the Law Lords disavowed a waiver theory.49 Also inconsistent with a waiver theory is the Law Lords' agreement that the relevant date in 1988 was not the date that Chile ratified the Convention, October 30, but rather the date that Britain ratified it, December 8.50

It appears, therefore, that most of the Law Lords relied on the theory that Pinochet's immunity was abrogated rather than waived. In other words, they concluded that something happened in or by 1988 that overrode Pinochet's immunity as a matter of law. For some - and perhaps most - of the Law Lords, the abrogation stemmed from the Torture Convention. ${ }^{51}$ The Convention's abrogation of former-head-of-state immunity would not likely have been effective with respect to the circumstances of the Pinochet case until all three interested countries - Spain, Chile, and Britain - had ratified the Convention. This would explain the Law Lords' holding that Pinochet's immunity was abrogated as of December 8 , the date of Britain's ratification, because Britain was the last of these three countries to ratify the treaty.

The abrogation theory nevertheless suffers from a number of difficulties. In a world of equal sovereign states, it is unclear why an abrogation of immunity can be accomplished by a weaker showing of consent than a waiver of immunity. A possible answer is that abrogation of immunity for torture was, as of 1988, a jus cogens norm - a rule of international law considered binding on nations

48. See [1999] 2 W.L.R. at 882 (Lord Hope), 857 (Lord Goff), 904 (Lord Saville).

49. See [1999] 2 W.L.R. at 886 (Lord Hope), 900 (Lord Hutton); see also [1999] 2 W.L.R. at 913 (Lord Millett) ("I do not regard [Chile] as having thereby waived its immunity. In my opinion there was no immunity to be waived."). But see [1999] 2 W.L.R. at 904 (Lord Saville) ("[I]t seems to me that the express and unequivocal terms of the Torture Convention fulfil any such [waiver] requirement.").

50. One Law Lord thought that October 30 was the appropriate date, but he was nonetheless "content to accept" the December 8 date. See [1999] 2 W.L.R. at 887 (Lord Hope).

51. We say "perhaps most" because the five Law Lords who believed that Pinochet's immunity was abrogated in 1988 invoked the Torture Convention in very different ways. Lords Browne-Wilkinson and Saville thought that the Torture Convention per se abrogated Pinochet's immunity. See [1999] 2 W.L.R. at 847 (Lord Browne-Wilkinson), 904 (Lord Saville). Lords Hutton and Millett agreed that Pinochet's immunity claim could not survive the Torture Convention, but they left open the possibility that it was abrogated prior to the Convention because of torture's status as a jus cogens crime. See [1999] 2 W.L.R. at 897-99 (Lord Hutton), 912 (Lord Millett). Lord Hope believed that Chile's ratification of the Convention was the event that abtogated Pinochet's immunity. He did not think that the Convention by itself caused this abrogation but thought instead that this was caused by the development of a CIL of international criminal law, of which the Convention constituted the final step. See [1999] 2 W.L.R. at 886-87 (Lord Hope). 
regardless of their consent.52 However, while it is true that several of the Law Lords described the prohibition on torture as a jus cogens norm - and Chile apparently conceded as much ${ }^{53}$ - none of them described the abrogation of immunity as such a norm. Indeed, several of the Law Lords who thought that Pinochet's immunity had been abrogated denied that the jus cogens status of the prohibition on torture was enough, by itself, to abrogate immunity. 54

Another problem with the abrogation theory, as with the waiver theory, is the absence of any reference to immunity in the Torture Convention. The plain language of the Convention makes torture a crime without speaking to the issue of whether particular violators can claim immunity from foreign court prosecution. The immunity issue also appears nowhere in the treaty's legislative history, or "travaux preparatoires." 55 These omissions seem especially significant in light of the fact that the drafters of a number of other international crimes treaties and statutes have seen fit to override immunity in express terms. ${ }^{56}$

52. See Vienna Convention on the Law of Treaties, May 23, 1969, art. 53, 1155 U.N.T.S. 332,344 (defining a jus cogens norm as "a norm accepted and recognized by the international community of States as a whole as a norm from which no derogation is permitted and which can be modified only by a subsequent norm of general international law having the same character").

53. See Second Law Lords' Decision, [1999] 2 W.L.R. at 841 (Lord Browne-Wilkinson), 898-99 (Lord Hutton), 912-13 (Lord Millett), 924 (Lord Phillips).

54. See [1999] 2 W.L.R. at 847 (Lord Browne-Wilkinson).

55. See [1999] 2 W.L.R. at 860 (Lord Goff), 884 (Lord Hope). The standard treatise on the Convention, which was coauthored by the Convention's Rapporteur (Burgers), is $\mathbf{J}$. Herman Burgers \& Hans Danelius, The United Nations Convention against Tor. TURE (1988). This book mentions immunity only once. In its commentary on the requirement in Article 5 of the Convention that a nation establish jurisdiction over a torture offense committed within its territory, the commentary notes that

[u]nder international or national law, there may be certain limited exceptions to this rule, e.g. in regard to foreign diplomats, foreign troops, parliament members or other categories benefiting from special immunities, and such immunities may be accepted in so far as they apply to criminal acts in general and are not unduly extensive.

Id. at 131. As Lord Hope noted, this passage is "so cryptic as to defy close analysis," Second Law Lords' Decision, [1999] 2 W.L.R. at 884 (Lord Hope), but it does appear to recognize that CIL immunities may be consistent with the Convention, and it further suggests that the framers of the Convention did not specifically consider the issue of former-head-of-state immunity.

56. See, e.g., Agreement for the Prosecution and Punishment of the Major War Criminals of the European Axis, Aug. 8, 1945, art. 7, 59 Stat. 1544, 1548, 82 U.N.T.S. 279, 288 (containing the Charter of the International Military Tribunal at Nuremberg) ("The official position of defendants, whether as Heads of State or responsible officials in Government Departments, shall not be considered as freeing them from responsibility or mitigating punishment."); Convention on the Prevention and Punishment of the Crime of Genocide, Dec. 9, 1948, art. 4, 102 Stat. 3045, 78 U.N.T.S. 277, 280 ("Persons committing genocide . . . shall be punished, whether they are constitutionally responsible rulers, public officials or private individuals."); Report of the Secretary-General Pursuant to Paragraph 2 of Security Council Resolution 808, U.N. SCOR, 48th Sess., at 15, U.N. Doc. S/25704 (1993), reprinted in 32 I.L.M. 
These reasons probably explain why most of the Law Lords who relied on the Torture Convention to abrogate Pinochet's immunity rested their conclusion more on the purposes of the Convention than on its language. ${ }^{57}$ Because the Convention applies only to offcial conduct, they argued that it would have little or no effect unless it abrogated official immunity. One strand of this argument emphasized that a former head of state is the person most likely to have been responsible for official acts of torture and thus should not be able to avoid the proscriptions of the Convention. ${ }^{58}$ Another strand emphasized that official immunities under CIL extend not only to heads of state, but also to other government officials carrying out state functions. As a result, the argument goes, if immunity is not abrogated, "the whole elaborate structure of universal jurisdiction over torture committed by officials. [would be] rendered abortive." 59

There are many potential objections to this purpose-based argument for abrogation of immunity. ${ }^{60}$ As Lord Goff's dissent noted, the availability of former-head-of-state immunity in foreign courts does not in fact negate the effect of the Convention. Most instances of torture by public officials will be committed in the state in which

1161,1194 (1993) (establishing the international tribunal for the former Yugoslavia and containing that tribunal's statute); S.C. Res. 955, U.N. SCOR, 49th Sess., 3453d mtg. at 6, U.N. Doc. S/RES/955 (1994), reprinted in 33 I.L.M. 1598, 1604 (1994) (establishing the international tribunal for Rwanda and containing that tribunal's statute) ("The official position of any accused person, whether as Head of State or Government or as a responsible Government official, shall not relieve such person of criminal responsibility nor mitigate punishment."); Rome Statute of the International Criminal Court, art. 27(1), U.N. Doc. A/CONF. $183 / 9$ (1998) ("[O]fficial capacity as a Head of State or Government . . . shall in no case exempt a person from criminal responsibility under this Statute, nor shall it, in and of itself, constitute a ground for reduction of sentence.").

57. See Second Law Lords' Decision, [1999] 2 W.L.R. at 847-48 (Lord Browne-Wilkinson), 914 (Lord Millett), 925 (Lord Phillips). Only Lord Saville thought the "express terms" of the Torture Convention abrogated former-head-of-state immunity. See [1999] 2 W.L.R. at 904 (Lord Saville). The "express terms" Saville had in mind are contained in Article 1 of the Convention, which states that the Convention applies to torture "inflicted by or at the instigation of or with the consent or acquiescence of a public official or other person acting in an official capacity." Torture Convention, supra note 2, art. 1, S. TREATY Doc. No. 100-20, at 19 (1988), 1465 U.N.T.S. at 114. Counsel for Chile conceded that this language encompasses heads of state but argued that the language did not abrogate immunity. See [1999] 2 W.L.R. at 854 (Lord Goff).

58. See, e.g., [1999] 2 W.L.R. at 847 (Lord Browne-Wilkinson) ("[I]f the former head of state has immunity, the man most responsible will escape liability while his inferiors (the chiefs of police, junior army officers) who carried out his orders will be liable.").

59. [1999] 2 W.L.R. at 847 (Lord Browne-Wilkinson).

60. According to Lord Goff, the argument was raised for the first time during the second hearing before the House of Lords, had previously "been overlooked by fourteen counsel (including three distinguished Professors of International Law) acting for the appellants and for Amnesty International and Human Rights Watch," and "receives no support from the literature on the subject[,] and ... appears never to have been advanced before." [1999] 2 W.L.R. at 856 (Lord Goff). 
the official resides, where the Convention's prohibition on torture will apply without any international immunity defense. In addition, the Convention's criminal prohibitions could also be applied by other nations in cases where the former-head-of-state's government is willing to waive immunity. Another problem with the purposebased immunity argument stems from the belief of several Law Lords that torture was an international crime under CIL prior to the Convention. ${ }^{61}$ These same Law Lords also believed that a former head of state retained immunity during this pre-Convention period. ${ }^{62}$ Yet they failed to explain why official immunities were consistent with the international crime of torture established by custom but not consistent with the international crime of torture established by treaty.

Perhaps the most significant problem with the purpose-based immunity abrogation theory derives from the Law Lords' insistence that current heads of state enjoy absolute immunity under international law for acts of torture even after the Torture Convention. ${ }^{63}$ The Convention criminalizes torture committed by public officials and others acting in an official capacity. It no more distinguishes between current and former heads of state than it does between former heads of state and lower-level officials. The logic of the immunity abrogation theory thus would seem to apply across the board to all public officials, or not at all. If immunity for current heads of state is not inconsistent with the purposes of the Convention, it is unclear why immunity for former heads of state is inconsistent with those purposes. Some of the Law Lords attempted to address this problem by pointing out that current-headof-state immunity attaches to the office, whereas former-head-ofstate immunity and lower-level official immunity apply only to particular conduct. ${ }^{64}$ This is simply to argue, however, that currenthead-of-state immunity is not abrogated by the Torture Convention because, unlike former-head-of-state immunity, it is absolute. This argument begs the question of why current-head-of-state immunity

61. See [1999] 2 W.L.R. at 840-41 (Lord Browne-Wilkinson), 886 (Lord Hope), 903 (Lord Saville), 911-12 (Millett).

62. See [1999] 2 W.L.R. at 847 (Lord Browne-Wilkinson), 886-87 (Lord Hope), 903 (Lord Saville), 912-14 (Lord Millett).

63. See [1999] 2 W.L.R. at 844-45 (Lord Browne-Wilkinson), 898 (Lord Hutton), 903 (Lord Saville), 912 (Lord Millett), 915-16 (Lord Phillips). But see [1999] 2 W.L.R. at 852-53 (Lord Goff) (concluding that the immunity would be absolute "except in regard to crimes in particular situations before international tribunals" (citing First Law Lords' Decision, [1998] 3 W.L.R. 1456, 1474 (H.L.) (Lord Slynn))).

64. See [1999] 2 W.L.R. at 902 (Lord Saville), 905-07 (Lord Millett). 
continues to be absolute after the Torture Convention when former-head-of-state immunity has been restricted.

In any event, this purpose-based theory of abrogation by the Torture Convention might not even have been the dispositive reason for the Law Lords' holding. Many Law Lords reasoned, or at least insinuated, that Pinochet's immunity was abrogated in or by 1988 not because of the Convention per se, but rather because of the status of torture as an "international crime" under CIL.65 The Law Lords were extraordinarily casual in their identification of torture as an international crime, relying in varying degrees on the writings of scholars, unadopted International Law Commission codes, and General Assembly resolutions that did not at the time of their issuance have the status of law. ${ }^{66}$ In addition, the Law Lords were imprecise regarding when torture became an international crime, and why. In these respects, the Pinochet decision continues a modern trend of identifying CIL not on the basis of customary practice, but rather on the basis of verbal consensus as reflected in technically nonlegal sources of law. ${ }^{67}$

More important than the casual identification of torture as an international crime was the confusion among the Law Lords regarding the very meaning and significance of the term "international crime." Lord Browne-Wilkinson thought that state torture was "an international crime in the highest sense" prior to the Torture Convention but that the prohibition on torture did not abrogate immunity until the time of the Convention because it was only at that point that torture was a "fully constituted international crime."68 By contrast, Lord Hope thought that, even after the Convention, the prohibition on torture did not abrogate immunity unless the torture was "on such a scale as to amount to an international crime." 69 Lord Hutton took issue with this point, ar-

65. Lord Hope expressly reasoned that Pinochet's immunity was abrogated by torture's status as an international crime, see [1999] 2 W.L.R. at 882-83 (Lord Hope); Lords Hutton and Millett insinuated that this might be so, see [1999] 2 W.L.R. at 899 (Lord Hutton), 911-13 (Lord Millett); and torture's status as an international crime figured prominently (though differently) in the opinions of Lords Browne-Wilkinson and Phillips, see [1999] 2 W.L.R. at 840-42 (Lord Browne-Wilkinson), 924-25 (Lord Phillips).

66. See, e.g., [1999] 2 W.L.R. at 840-41 (Lord Browne-Wilkinson), 853 (Lord Goff), 912 (Lord Millett).

67. For descriptions and analysis of this trend, compare Richard B. Lillich, The Growing Importance of Customary International Human Rights Law, 25 GA. J. INTL. L. 1 (1996) (arguing in favor of trend), with Bruno Simma \& Philip Alston, The Sources of Human Rights Law: Custom, Jus Cogens, and General Principles, 12 AusTL. Y.B. INTL. L. 82 (1992) (criticizing trend).

68. Second Law Lords' Decision, [1999] 2 W.L.R. at 841, 847 (Lord Browne-Wilkinson).

69. [1999] 2 W.L.R. at 885 (Lord Hope). 
guing that, at least after the Convention, a single act of state torture is an international crime that abrogates immunity. ${ }^{70}$ Lord Millett agreed that Pinochet's alleged torture constituted an international crime, but he rejected the notion that Pinochet had a preexisting immunity from criminal process that needed abrogating. ${ }^{71}$ In addition to these points, some of the Law Lords emphasized that the international criminal prohibition on torture was a jus cogens norm or was subject to universal jurisdiction. ${ }^{72}$ As other Law Lords pointed out, however, neither the jus cogens status of a crime nor the availability of universal jurisdiction over a crime by itself eliminates immunity. ${ }^{73}$

In sum, a majority of the Law Lords concluded that international law did not provide Pinochet with immunity from criminal extradition process in Britain. Their opinions, however, reveal substantial disagreement and confusion over why this was so. Even though the Law Lords had the benefit of briefing and argument by Britain's finest attorneys and international law scholars, the Law Lords could not agree even on which aspect of international law abrogated Pinochet's immunity or how this abrogation was accomplished. ${ }^{74}$

\section{PINOCHET AND the INTERnational LAW OVERRIDE STRATEGY}

Most international human rights law, like international law generally, applies only when there is a state action. ${ }^{75}$ As a result, immunities from suit for foreign officials guaranteed by both international law and domestic law constitute a major hurdle to human rights litigation in domestic courts. We have just seen that the Law Lords in Pinochet interpreted the Torture Convention and

70. See [1999] 2 W.L.R. at 901 (Lord Hutton).

71. See [1999] 2 W.L.R. at 912-13 (Lord Millett).

72. See, e.g., [1999] 2 W.L.R. at 898 (Lord Hutton).

73. See [1999] 2 W.L.R. at 847-48 (Lord Browne-Wilkinson), 881 (Lord Hope).

74. As we explain below in Part V, the vagueness of the sources and content of the international law at issue in Pinochet is typical of international human rights law in general, and it helps explain why the United States has been cautious in its incorporation of this law into its domestic legal system.

75. Except for a few categories of conduct, such as genocide and war crimes, individuals acting on their own cannot violate international human rights law. This is true even for egregious human rights abuses, such as torture. The Torture Convention covers conduct by "a public official or other person acting in an official capacity." Torture Convention, supra note 2, art. 1(1) (emphasis added). Such private conduct presumably will violate relevant domestic law, but it does not violate international law. See, e.g., Kadic v. Karadzic, 70 F.3d 232, 243 (2d Cir. 1995); Carmichael v. United Technologies Corp., 835 F.2d 109, 114 (5th Cir. 1988); Beanal v. Freeport-McMoran, 969 F. Supp. 362, 380 (E.D. La. 1997). 
CIL to limit Pinochet's immunity from criminal prosecution not only under international law, but also under Britain's domestic immunity statute. In effect, the Law Lords held that developments in international law abrogated Pinochet's immunity on the domestic plane. Plaintiffs in human rights litigation in the United States can be expected to invoke this aspect of the Pinochet decision as a basis for overcoming immunity hurdles in U.S. courts.

The Law Lords considered developments in international law relevant to Pinochet's immunity in British courts because Britain's State Immunity Act limits former-head-of-state immunity to acts performed in the exercise of official functions, ${ }^{76}$ and the Law Lords interpreted this standard as incorporating developing international law standards. Ultimately, therefore, British domestic law determined the relevance of international law to Pinochet's immunity on the domestic plane. As we explain below, however, Great Britain and the United States have different rules governing how the international laws at issue in the Pinochet case operate within their domestic legal systems. In the United States, the federal political branches have not authorized the incorporation of developing norms of international law to narrow the immunities available in U.S. courts, and federal courts generally have declined to embrace an "international law override" of these immunities on their own authority. ${ }^{77}$ Not only does the Pinochet decision not provide support for such an override in U.S. courts, in several ways it actually suggests reasons for rejecting one.

\section{A. Potential Relevance of Pinochet to U.S. Litigation}

In this section, we explain why immunity issues analogous to the ones at issue in Pinochet are likely to arise in the United States primarily in the context of civil human rights litigation rather than criminal extradition. We also explain how the House of Lords' construction of the British immunity statute might appear at first glance to be relevant to this civil litigation.

Criminal Extradition. Courts in the United States are unlikely to address the international law immunity issues presented in Pinochet in the criminal extradition context. To see why, consider

76. See supra text accompanying notes 20-23.

77. There is nothing unusual in the fact that Great Britain and the United States have different rules concerning whether and how international human rights law affects domestic immunities for foreign officials. International law does not specify how nations must treat international obligations as a matter of domestic law, and nations often differ as to whether and how to incorporate international law into their domestic legal systems. See LouIS HENKIN ET AL., INTERNATIONAL LAW: CASES AND MATERIALS 153 (3d ed. 1993). 
what would happen if Pinochet had come to New York rather than London for his back operation and, while there, the United States received an extradition request from Spain. Spain and the United States have an extradition treaty that provides for extradition for extraterritorial crimes. ${ }^{78}$ In addition, the United States has a criminal prohibition on extraterritorial torture similar to the one in Britain's Criminal Justice Act of $1988 . .^{79}$ For these reasons, Pinochet would potentially be subject to extradition from the United States to Spain for acts of torture committed in Chile. ${ }^{80}$

But would Pinochet as a former head of state be immune from this criminal extradition process? Here there are large differences between U.S. and British law. As discussed above, the British immunity statute expressly provides current heads of state with absoIute immunity from criminal process, and it provides former heads of state with qualified immunity. ${ }^{81}$ By contrast, the primary basis of immunity for foreign sovereigns and their officials in the United States - the Foreign Sovereign Immunities Act ${ }^{82}$ - applies only in civil cases. ${ }^{83}$ Unlike in Britain, there is no statutory basis in the United States for current- or former-head-of-state immunity from criminal process. As we explain more fully below, the availability of such immunity in the United States is instead a largely discretionary decision by the executive branch. ${ }^{84}$ Courts faced with official immunity issues in a criminal extradition context do not look to international law; rather, they follow the wishes of the executive branch, which in turn makes its decisions without necessarily following international law. ${ }^{85}$ Because of this difference between U.S. and British immunity law, the immunity holding in Pinochet will have little effect on U.S. criminal extradition practice unless and to the extent that the executive branch decides to follow it.

Civil Litigation. To say that the Pinochet decision has little relevance in the criminal extradition context in the United States is not

78. See Treaty on Extradition Between the United States of America and Spain, May 29, 1970, art. III(B), 22 U.S.T. 737, 740.

79. See 18 U.S.C.A. § 2340A (Supp. 1998).

80. Unlike the British Extradition Act, the United States extradition statute does not purport to regulate either extraterritorial crimes or the principle of double criminality. See 18 U.S.C. \$§ 3184-95. Instead, these issues are governed in U.S. courts in accordance with the particular extradition treaty at issue.

81. See supra notes 20-23 and accompanying text.

82. Foreign Sovereign Immunities Act of 1976, Pub. L. No. 940583, 90 Stat. 2892 (codified as amended at 28 U.S.C. $\$ \$ 1330,1602-1611(1994))$.

83. See 28 U.S.C. $\$ 1602$.

84. See infra Part IV.A-B.

85. See e.g., United States v. Noriega, 117 F.3d 1206, 1212 (11th Cir. 1997). 
to say that it has no relevance in U.S. courts. Courts in the United States have for years been grappling with international law issues similar to those presented in Pinochet in civil suits alleging violations of international human rights law by foreign officials. Indeed, the parties and judges in the Pinochet case drew heavily on U.S. civil litigation case law in assessing whether Pinochet was immune from criminal process in England. ${ }^{86}$ Plaintiffs in U.S. human rights litigation can be expected, in turn, to invoke the Pinochet decision in support of their efforts to overcome the immunity of foreign officials. To understand why Pinochet is not likely to support these efforts, it is necessary first to review the statutory basis for human rights litigation and official immunity from civil suit in the United States.

The principal statutory vehicle for international human rights litigation in U.S. courts has been the Alien Tort Statute (ATS) ${ }^{87}$ This statute, which originally was enacted as part of the Judiciary Act of 1789 , states that federal district courts shall have jurisdiction to hear "any civil action by an alien for a tort only, committed in violation of the law of nations or a treaty of the United States."88 Although the statute rarely was invoked during the first 190 years of its existence, ${ }^{89}$ it assumed new significance in the 1980 Filartiga $v$. Pena-Irala decision. ${ }^{90}$ That decision held that the ATS authorizes federal court jurisdiction over suits between aliens for human rights abuses committed abroad and that such jurisdiction is consistent with Article III of the Constitution. ${ }^{91}$

86. See supra text accompanying note 40 .

87. 28 U.S.C. $\$ 1350$.

88. 28 U.S.C. $\S 1350$. The original purposes of the ATS are uncertain. For various perspectives, see Curtis A. Bradley \& Jack L. Goldsmith, The Current Illegitimacy of International Human Rights Litigation, 66 FordHAM L. Rev. 319, $357-63$ (1997) [hereinafter The Current Illegitimacy]; Anne-Marie Burley, The Alien Tort Statute and the Judiciary Act of 1789: A Badge of Honor, 83 AM. J. INTL. L. 461, 475-80 (1989); William R. Casto, The Federal Courts' Protective Jurisdiction over Torts Committed in Violation of the Law of Nations, 18 Conn. L. Rev. 467, 499-510 (1986); William S. Dodge, The Historical Origins of the Alien Tort Statute: A Response to the "Originalists," 19 Hastings INTL. \& Comp. L. Rev. 221, 225-37 (1996); John M. Rogers, The Alien Tort Statute and How Individuals "Violate" International Law, 21 VAND. J. TRANSNATL. L. 47, 48-60 (1988); Joseph Modeste Sweeney, $A$ Tort Only in Violation of the Law of Nations, 18 Hastings INTL. \& COMP. L. REv. 445, 44647 (1995). For the best textual analysis of the ATS, see John C. Harrison, The Law of Nations as Law of the United States in the Judiciary Act of 1789 (unpublished draft on file with authors).

89. In 1975, Judge Henry Friendly referred to the ATS as an "old but little used section" and as a "kind of legal Lohengrin," and stated that "no one seems to know whence it came." IIT v. Vencap, Ltd., 519 F.2d 1001, 1015 (2d Cir. 1975).

90. 630 F.2d 876 (2d Cir. 1980).

91. See Filartiga, 630 F.2d at 885 . For a discussion of the Article III issue, see infra text accompanying notes $189-91$. 
The ATS does not purport to override the immunity of foreign governments or officials. As noted above, the principal source of immunity from civil suit in the United States for foreign governments and officials is the Foreign Sovereign Immunities Act (FSIA). ${ }^{92}$ The FSIA provides foreign states with presumptive immunity from civil suit unless their conduct falls within one of the statutory exceptions to immunity..$^{93}$ In Argentine Republic $v$. Amerada Hess Shipping Corp., ${ }^{94}$ the Supreme Court held that the FSIA constitutes the exclusive basis for the exercise of jurisdiction over a foreign state, even with respect to cases that otherwise would satisfy the terms of the ATS. ${ }^{95}$

The FSIA does not refer to suits against individual officials of foreign governments. Rather, it refers to suits against a "foreign state," 96 which is defined to include "a political subdivision of a foreign state or an agency or instrumentality of a foreign state."97 The FSIA's legislative history lists state corporations and agencies but not individuals as examples of what is meant by the term "foreign state."98 Numerous courts nonetheless have held that the FSIA applies to individual officials acting in an official capacity. ${ }^{99}$ These courts have reasoned that when foreign officials act within the scope of their official duties, their acts are the state's acts and must accordingly receive sovereign immunity. ${ }^{100}$ In addition, these courts note that if individuals were not covered by the FSIA, plain-

92. 28 U.S.C. $\$ \S 1330,1602-1611$ (1994).

93. See 28 U.S.C. $\$ 1604$.

94. 488 U.S. 428 (1989).

95. See 488 U.S. at 438.

96. See 28 U.S.C. $\$ 1602$.

97. 28 U.S.C. $\$ 1603($ a). Agency or instrumentality is in turn defined as, among other things, "any entity" that is "a separate legal person." 28 U.S.C. $\$ 1603(\mathrm{~b})$ (emphasis added).

98. See H.R. REP. No. 94-1487, at 15-16 (1976), reprinted in 1976 U.S.C.C.A.N. 6604, 6613-14.

99. See, e.g., Junquist v. Nahyan, 115 F.3d 1020, 1027 (D.C. Cir. 1997); Phaneuf v. Republic of Indonesia, 106 F.3d 302, 306 (9th Cir. 1997); El-Fadl v. Central Bank of Jordan, 75 F.3d 668, 671 (D.C. Cir. 1996); Chuidian v. Philippine Natl. Bank, 912 F.2d 1095, 1103 (9th Cir. 1990); Trujillo v. Banco Cent. Del Ecuador, 17 F. Supp. 2d 1340, 1343-44 (S.D. Fla. 1998); Granville Gold Trust-Switzerland v. Commissione Del Fallimento/Interchange Bank, 928 F. Supp. 241, 243 (E.D.N.Y. 1996); Cabiri v. Assasie-Gyimah, 921 F. Supp. 1189, 1197 (S.D.N.Y. 1996); Intercontinental Dictionary Series v. De Gruyter, 822 F. Supp. 662, 674 (C.D. Cal. 1993); Kline v. Kaneko, 685 F. Supp. 386, 389 (S.D.N.Y. 1988); American Bonded Warehouse Corp. v. Compagnie Nationale Air France, 653 F. Supp. 861, 863 (N.D. Ill. 1987); Mueller v. Diggelman, No. 82 Civ. 5513, 1983 U.S. Dist. LEXIS 16970, at *4 (S.D.N.Y. May 13, 1983); Rios v. Marshall, 530 F. Supp. 351, 371 (S.D.N.Y. 1981). But see Republic of Philippines v. Marcos, 665 F. Supp. 793, 797 (N.D. Cal. 1987) ("[T]he sovereign immunity doctrine . . . is not applicable to individual government officials.").

100. See, e.g., Chuidian, 912 F.2d at 1101-02. 
tiffs could render the statute ineffective simply by suing a state's officials rather than the state itself. 101

The FSIA's immunities for foreign states and officials are in obvious tension with the international human rights litigation found in Filartiga and other decisions to be authorized by the ATS. ${ }^{102}$ And it is clear from Amerada Hess that the FSIA takes precedence over the ATS. To circumvent the immunity bar, plaintiffs in human rights cases have invoked ambiguities in the FSIA in an effort to persuade courts to recognize exceptions to immunity. ${ }^{103}$ In particular, they have argued in various ways that the FSIA should be read to permit an exception to immunity for gross violations of international human rights law. ${ }^{104}$ Such a construction of the FSIA appears at first glance to be similar to the construction of the British immunity statute adopted by the Law Lords in Pinochet. As a result, plaintiffs in human rights cases are likely to invoke the Pinochet precedent in their efforts to override FSIA immunities.

\section{B. U.S. Rejection of the International Law Override Strategy}

As we explain in this section, U.S. courts have rejected attempts to create an international human rights law exception to the FSIA. These courts have relied on both particular features of U.S. law as well as broader constitutional principles. Given this reasoning, U.S. courts are unlikely to embrace the logic of the Pinochet decision.

No general international law exception. The FSIA contains no general exception to immunity for violations of international law. As enacted in 1976, the FSIA contained a single specific exception relating to a violation of international law - an exception for certain takings of property. ${ }^{105}$ In Amerada Hess, the Supreme Court inferred from this exception that other violations of international law do not constitute exceptions to immunity under the FSIA. ${ }^{106}$ In a subsequent decision, the Court held that even torture - the conduct at issue in Pinochet - can be sovereign conduct subject to the presumptive immunity of the FSIA. ${ }^{107}$

101. See, e.g., Chuidian, 912 F.2d at 1102.

102. See generally David J. Bederman, Dead Man's Hand: Reshuffling Foreign Sovereign Immunities in U.S. Human Rights Litigation, 25 GA. J. INrL. L. 255 (1995/1996).

103. See infra text accompanying notes 105-29.

104. See infra text accompanying notes 108-14.

105. See 28 U.S.C. \& 1605(a)(3) (1994).

106. See Argentine Republic v. Amerada Hess Shipping Corp., 488 U.S. 428, 435-36 (1989).

107. See Saudi Arabia v. Nelson, 507 U.S. 349, 361 (1993) (reasoning that "however monstrous such abuse undoubtedly may be, a foreign state's exercise of the power of its police has 
No jus cogens waiver exception. Faced with a rejection of a general international law exception to immunity, plaintiffs and some commentators have proposed an exception for fundamental, or " jus cogens," norms of international human rights law. ${ }^{108}$ As noted above, a jus cogens norm is "accepted and recognized by the international community of States as a whole as a norm from which no derogation is permitted." 109 Although the FSIA contains no general exception to immunity for violations of international human rights law, it does contain an exception to immunity for situations where the foreign state "has waived its immunity either explicitly or by implication." 110 Plaintiffs and commentators have invoked this exception to argue that foreign governments waive their immunity by implication when they violate jus cogens norms of international human rights law, such as the prohibitions on genocide, war crimes, and torture.

The three federal appeals courts that have considered this argument (or a variation of it) have rejected it.111 These courts have emphasized that the governing law is the domestic FSIA, not international law, and that the FSIA contains no jus cogens exception. ${ }^{112}$ The most recent of these decisions noted that Congress amended the FSIA after the earlier decisions but failed to enact any general jus cogens exception to the FSIA, thereby suggesting that "Congress is not necessarily averse to permitting some violations of jus cogens to be redressed through channels other than suits against

long been understood for purposes of the restrictive theory as peculiarly sovereign in nature").

108. For commentary to this effect, see, for example, Adam C. Belsky et al., Comment, Implied Waiver Under the FSIA: A Proposed Exception to Immunity for Violations of Peremptory Norms of International Law, 77 CAL. L. Rev. 365 (1989), Thora A. Johnson, $A$ Violation of Jus Cogens Norms as an Implicit Waiver of Immunity Under the Foreign Sovereign Immunities Act, 19 MD. J. INTL. L. \& TRADE 259 (1995). For examples of similar plaintiffs' claims, see infra note 111. 334.

109. Vienna Convention on the Law of Treaties, supra note 52, art. 53, 1155 U.N.T.S. at

110. 28 U.S.C. $\S 1605(a)(1)$.

111. See Smith v. Socialist People's Libyan Arab Jamahiriya, 101 F.3d 239, 245 (2d Cir. 1996); Princz v. Federal Republic of Germany, 26 F.3d 1166, 1174 (D.C. Cir. 1994); Siderman de Blake v. Republic of Argentina, 965 F.2d 699, 714-19 (9th Cir. 1992); see also Sampsom v. Federal Republic of Germany, 975 F. Supp. 1108, 1123 (N.D. Ill. 1997); Denegri v. Republic of Chile, No. 86-3085, 1992 U.S. Dist. LEXIS 4233, at *11-12 (D.D.C. April 3, 1992). See generally Garland A. Kelly, Note, Does Customary International Law Supersede a Federal Statute?, 37 Colum. J. TRANSNATL. L. 507 (1999) (describing and defending these decisions).

112. By contrast, one dissenting judge has argued that the FSIA should be interpreted not to give more immunity in this context than is conferred under international law. See Princz, 26 F.3d at 1176 (Wald, J., dissenting). That judge reasoned that "the clear import of international law is to disavow a foreign sovereign's claims to immunity where that sovereign is accused of violating universally accepted norms of conduct essential to the preservation of the international order." 26 F.3d at 1183. 
foreign states in United States courts."113 The court also noted that "Congress might well have expected the response to [allegations of terrorism] to come from the political branches of the Government, which are not powerless to penalize a foreign state for international terrorism." 114 In short, courts have recognized that there are means of redress for human rights abuses other than civil suits in U.S. courts, and they have insisted that even the most fundamental norms of international human rights law do not override domestic immunities until Congress says so.

No international treaty exception. Plaintiffs and scholars also have attempted to override domestic immunities for international human rights law violations by relying on the FSIA's treaty exception. The FSIA's presumptive immunity is "[s]ubject to existing international agreements to which the United States [was] a party at the time of [the FSIA's] enactment."115 The Supreme Court in Amerada Hess interpreted this provision to apply only "when international agreements 'expressly conflic[t]' with the immunity provisions of the FSIA."116 The Court further noted that a foreign nation does not "waive its immunity . . . by signing an international agreement that contains no mention of a waiver of immunity to suit in United States courts or even the availability of a cause of action in the United States."117 A number of lower courts have concluded, following Amerada Hess, that a nation's ratification of a human rights treaty does not constitute a waiver of the nation's immunity from U.S. judicial process unless the treaty itself contains a waiver or confers a private cause of action. ${ }^{118}$

No human rights exception to head-of-state immunity. As we explain in some detail in the next Part, both before and after the enactment of the FSIA courts have looked to the political branches for authorization to apply head-of-state immunity. ${ }^{119}$ Because the FSIA does not by its terms refer to heads of state, most courts have sought this authorization from the executive branch in the form of

113. Smith, 101 F.3d at 244.

114. Smith, 101 F.3d at 244.

115. 28 U.S.C. $\$ 1604$.

116. Argentine Republic v. Amerada Hess Shipping Corp., 488 U.S. 428, 442 (1989) (quoting H.R. REP. No. 94-1487, at 17 (1976), reprinted in 1976 U.S.C.C.A.N. 6604, 6615-16 and S. Rep. No. 94-1310, at 17 (1976)).

117. Amerada Hess Shipping Corp., 488 U.S. at $442-43$.

118. See Princz v. Federal Republic of Germany, 26 F.3d 1166, 1175 (D.C. Cir. 1994); Siderman de Blake v. Republic of Argentina, 965 F.2d 699, 719-20 (9th Cir. 1992); Saltany v. Reagan, 886 F.2d 438, 441 (D.C. Cir. 1989); Sampson v. Federal Republic of Germany, 975 F. Supp. 1108, 1119 (N.D. Ill. 1997).

119. See infra Part IV.A-B. 
an executive suggestion. ${ }^{120}$ In so doing, courts have recognized head-of-state immunity even in the face of alleged violations of international criminal and human rights law. ${ }^{121}$ The basis and scope of former-head-of-state immunity are less certain, ${ }^{122}$ but nothing in the case law suggests a human rights exception to this immunity. ${ }^{123}$

The discretionary function anomaly. Plaintiffs also have attempted to create an international law override to the FSIA through its "non-commercial tort" exception, which denies immunity for torts that cause injury or damage in the United States. ${ }^{124}$ This exception in turn contains its own exception that preserves immunity for claims "based upon the exercise or performance or the failure to exercise or perform a discretionary function." 125 Courts are divided over whether illegal acts can be discretionary for these purposes. ${ }^{126}$ Most important for now, however, is the district court decision, Letelier $v$. Republic of Chile, ${ }^{127}$ suggesting in this context

120. See infra text accompanying notes 184-87.

121. See, e.g., Lafontant v. Aristide, 844 F. Supp. 128, 137-39 (E.D.N.Y. 1994) (granting immunity to President Aristide of Haiti in a suit alleging violations of international human rights law); Saltany v. Reagan, 702 F. Supp. 319, 320 (D.D.C. 1988) (granting immunity to Prime Minister Margaret Thatcher in a suit alleging violations of international law relating to her assistance with air strikes in Libya); Kilroy v. Windsor, No. C 78-291 (N.D. Ohio 1978), excerpted in State Representation, 1978 Digest $\$ 3$, at 641-43 (granting immunity to the Prince of Wales in a suit alleging that he was responsible for human rights violations in Northern Ireland); see also Flatow v. Islamic Republic of Iran, 999 F. Supp. 1, 24 (D.D.C. 1998) (assuming that head-of-state immunity ordinarily would apply to "state sponsorship of terrorism" because such conduct involves a "decision made at the highest levels of government").

122. See generally Peter Evan Bass, Note, Ex-Head of State Immunity: A Proposed Statutory Tool of Foreign Policy, 97 YALE L.J. 299 (1987).

123. Most former-head-of-state immunity claims have been resolved on the basis of waiver. See, e.g., In re Doe, 860 F.2d 40, $45-46$ (2d Cir. 1988); In re Grand Jury Proceedings, 817 F.2d 1108, 1110-11 (4th Cir. 1987); Paul v. Avril, 812 F. Supp. 207, 211 (S.D. Fla. 1993). Some courts have suggested in dicta that former-head-of-state immunity does not extend to private (as opposed to official) acts. See, e.g., In re Doe, 860 F.2d at 44 (dicta); Republic of the Philippines v. Marcos, 806 F.2d 344, 360 (2d Cir. 1986) (dicta); United States v. Noriega, 746 F. Supp. 1506, 1519 n.11 (S.D. Fla. 1990) (dicta); $c f$. Trajano v. Marcos, No. 86-0207, 1986 U.S. Dist. LEXIS 22541 , at $* 17$ (D. Haw. July 18,1986 ) (noting, in response to claim of former-head-of-state immunity, that "[u]ntil such time as head of state immunity is made a creature of judicial interpretation, this court will not intrude on the prerogative of the executive branch to make such determinations"); Roxas v. Marcos, 969 P.2d 1209, 1252 (Haw. 1998) (questioning, perhaps in dicta, the availability of immunity to former heads of state).

124. See 28 U.S.C. § 1605 (a)(5) (1994).

125. $\$ 1605(\mathrm{a})(5)(\mathrm{A})$. See generally Sienho Yee, Note, The Discretionary Function Exception Under the Foreign Sovereign Immunities Act: When in America, Do the Romans Do as the Romans Wish?, 93 Colum. L. Rev. 744 (1993).

126. Courts holding that an illegal act can be discretionary include Risk $v$. Halvorsen, 936 F.2d 393, 397 (9th Cir. 1991); MacArthur Area Citizens Assn. v. Republic of Peru, 809 F.2d 918, 922 n.4 (D.C. Cir. 1987); Kline v. Kaneko, 685 F. Supp. 386, 392 (S.D.N.Y. 1988). By contrast, in Liu v. Republic of China, 892 F.2d 1419, 1431 (9th Cir. 1989), the court held that foreign officials did not have discretion to commit a clear violation of their own domestic law.

127. 488 F. Supp. 665 (D.D.C. 1980). 
that there is no discretion to commit a clear violation of international law. ${ }^{128}$ The court concluded that Chile's alleged involvement in the assassination of former Chilean officials in the United States was not discretionary because it was "clearly contrary to the precepts of humanity as recognized in both national and international law."129

Letelier is the only decision of which we are aware suggesting that international law might abrogate immunity within the U.S. domestic legal system. Even if the Letelier decision correctly interpreted the scope of the discretionary function exception, the decision has limited significance to human rights litigation because such litigation almost always involves human rights abuses committed on foreign soil, while the noncommercial tort exception applies only in situations where the injury or damage occurs in the United States. In any event, the Letelier analysis is difficult to reconcile with the Supreme Court's later decision in Amerada Hess. The insistence of Amerada Hess and its progeny that the only international law-related exceptions to immunity under the FSIA must appear on the face of the statute likely sounded the death knell for Letelier's discretionary function analysis.

Individual Capacity Suits. Although the FSIA is generally applicable in human rights suits brought against foreign government officials, ${ }^{130}$ some courts have concluded that certain human rights suits against individuals do not implicate the FSIA. ${ }^{131}$ These courts interpret the FSIA to extend immunity only to individuals acting in an official capacity, and the courts look to foreign law to determine whether the individuals accused of human rights abuses were so acting. If the alleged human rights abuses are not authorized under the foreign official's domestic law, these courts conclude that the abuses are beyond the official's scope of authority and thus outside

128. Coincidentally for purposes of this article, that case also involved alleged conduct by Pinochet's government.

129. Letelier, 488 F. Supp. at 673; see also Alicog v. Kingdom of Saudi Arabia, 860 F. Supp. 379, 383 (S.D. Tex. 1994) (stating in dicta that "[k]idnapping, private imprisonment, and assassination are all beyond the scope of legitimate diplomatic operations and are not protected by the discretionary function exception, and courts have jurisdiction over a government committing those acts").

130. See supra note 99 and accompanying text.

131. See Hilao v. Marcos, 25 F.3d 1467, 1470 (9th Cir. 1994); Cabiri v. Assasie-Gyimah, 921 F. Supp. 1189, 1198 (S.D.N.Y. 1996); Xuncax v. Gramajo, 886 F. Supp. 162, 174-76 (D. Mass. 1995). This case law is not uniform; a number of courts have applied the FSIA to individual officials who allegedly engaged in abusive and illegal conduct. See, e.g., Herbage v. Meese, 747 F. Supp. 60, 67 (D.D.C. 1990) (alleged improper arrest and extradition); Kline v. Kaneko, 685 F. Supp. 386, 389 (S.D.N.Y. 1988) (alleged expulsion from country without due process). 
of the official immunities conferred by the FSIA. The absence of immunity in these cases does not turn on the foreign official's violation of international law. These cases thus do not represent an international law override of the FSIA. ${ }^{132}$

Congressional responses. Human rights activists often have complained to Congress regarding the limitations on human rights litigation, including the restrictions imposed by domestic immunity law. Congress's responses to these complaints have been limited and targeted, further confirming that immunity should be available even for human rights abuses unless and until Congress creates an exception. For example, in response to concerns that international human rights law might not provide a private right of action, ${ }^{133}$ Congress enacted the Torture Victim Protection Act (TVPA). ${ }^{134}$ This 1992 statute created a federal cause of action against foreign officials who under color of state law commit torture or extrajudicial killings. Nothing on the face of the TVPA overrides the immunities of the FSIA, and the TVPA's legislative history makes clear that the TVPA is "subject to restrictions in the [FSIA]."135 The leg-

132. Traditionally, the act of state doctrine might have precluded courts in individual capacity cases from inquiring into the validity of foreign acts under foreign law. See Underhill v. Hernandez, 168 U.S. 250, 252 (1897) ("[C]ourts of one country will not sit in judgment on the acts of the government of another done within its own territory."). In Banco Nacional de Cuba v. Sabbatino, 376 U.S. 398 (1964), however, the Supreme Court held that the act of state doctrine is based on domestic separation of powers considerations rather than (as previously been the case) international law. See 376 U.S. at 421-23. The Court expressed particular concern that judicial inquiry into the validity of foreign government acts might interfere with the executive branch's conduct of foreign relations. See 376 U.S. at 431-33. One consequence of this new conception of the act of state doctrine is that the doctrine is limited to the official, public acts of a foreign government. Only an adjudication of those acts, courts have reasoned, is likely to embarrass the executive branch in its conduct of foreign relations. See Lynn E. Parseghian, Defining the "Public Act" Requirement in the Act of State Doctrine, $58 \mathrm{U}$. CHI. L. Rev. 1151 (1991) (collecting cases). Invoking this limitation, some courts have concluded that the adjudication of alleged human rights abuses not authorized by a foreign government are not "public acts" and thus are not covered by the act of state doctrine. See, e.g., Hilao, 25 F.3d at 1471 (describing earlier decision); Liu v. Republic of China, 892 F.2d 1419, 1431-34 (9th Cir. 1989); Forti v. Suarez-Mason, 672 F. Supp. 1531, 1546 (N.D. Cal. 1987).

133. These concerns were fueled by Judge Bork's concurring opinion in Tel-Oren $v$. Libyan Arab Republic, 726 F.2d 774 (D.C. Cir. 1984), in which he argued that CIL does not ordinarily confer a private right of action. See 726 F.2d at 816-19. For three recent decisions refusing to imply a private right of action under international human rights law, see Heinrich v. Sweet, 1999 U.S. Dist. LEXIS 6669 (D. Mass. Apr. 30, 1999), Hawkins v. ComparatCassani, 33 F. Supp. 2d 1244 (C.D. Cal. 1999) and White v. Paulsen, 997 F. Supp. 1380 (E.D. Wash. 1998). These courts noted the adequacy of domestic legal protections, the limited nature of Congress's codification of international human rights law in the Torture Victim Protection Act, see infra note 134, and the fact that the domestic enforcement of international human rights law is primarily the responsibility of Congress and the Executive rather than the courts.

134. Pub. L. No. 102-256, 106 Stat. 73 (1992) (set forth in statutory note following Alien Tort Statute, 28 U.S.C. $\$ 1350$ (1994)).

135. H.R. ReP. No. 102-367, at 5 (1991), reprinted in 1992 U.S.C.C.A.N. 84, 88. The Senate Report similarly states that the TVPA "is not meant to override the Foreign 
islative history further states that "nothing in the TVPA overrides the doctrines of diplomatic and head of state immunity."136 Similarly, other human rights and terrorism-related statutes, such as the Genocide Convention Implementation Act ${ }^{137}$ and the Act for the Prevention and Punishment of the Crime of Hostage-Taking, ${ }^{138}$ do not purport to override immunities from suit.

There have been many calls in recent years for Congress to create exceptions to FSIA immunity for human rights abuses, and a number of bills to this effect have been introduced in Congress. ${ }^{139}$ These efforts resulted in the enactment in 1996 of a very narrow human rights exception to immunity. This new exception removes immunity for torture, extrajudicial killing, and certain terrorist acts, but only when committed by nations that have been deemed sponsors of terrorism, and only in cases where the victim or claimant is a U.S. national. ${ }^{40}$ Only seven nations - Cuba, Iran, Iraq, Libya, North Korea, Sudan, and Syria - are currently deemed sponsors of terrorism. ${ }^{141}$ Even in these limited circumstances, plaintiffs invoking the new exception face an exhaustion requirement, discovery restrictions, and a statute of limitations. ${ }^{142}$ Against the background of Amerada Hess, this narrow and precise exception to immunity suggests that, in cases not covered by the exception, immunity remains available even with respect to egregious human rights abuses.

Sovereign Immunities Act ...." S. REP. No. 102-249, at 7 (1991). The Senate Report also states, however, that "[t]he legislation uses the term 'individual' to make crystal clear that foreign states or their entities cannot be sued under this bill under any circumstances: only individuals may be sued." S. REP. No. 102-249, at 7. Because the courts had held long before the TVPA that government officials acting in their official capacities come within the FSIA's immunities, see supra text accompanying note 99 , and since the legislative history makes clear that the TVPA was not meant to override the FSIA, the reference to "individuals" presumably means foreign officials acting in excess of their official capacities, for in this context the FSIA has been interpreted not to confer immunity, see supra notes 130-32 and accompanying text.

136. H.R. REP. No. 102-367, at 5; see also S. REP. No. 102-249, at 7-8 ("The TVPA is not intended to override traditional diplomatic immunities .... Nor should visiting heads of state be subject to suit under the TVPA.").

137. 18 U.S.C. $\S 1091$ (1988).

138. Pub. L. No. 98-473, 98 Stat. 2186 (1984).

139. See Jeffrey Jacobson, Note, Trying To Fit a Square Peg into a Round Hole: The Foreign Sovereign Immunities Act and Human Rights Violations, 19 WHrrTIER L. REV. 757, 773-75 (1998) (recounting these efforts).

140. See Antiterrorism and Effective Death Penalty Act of 1996, 28 U.S.C. $\S 1605(a)(7)$ (Supp. III 1997).

141. See 28 U.S.C. $\S 1605(a)(7)$. These nations are presently deemed to be state sponsors of terrorism under 50 U.S.C. app. $\$ 2405(j)(1994)$ and 22 U.S.C. \$ 2371 (1994). See 22 C.F.R. $\S 126.1(\mathrm{~d})$ (1998).

142. See 28 U.S.C. $\S 1605(a)(7)(B)(i),(f),(g)$. 
In sum, U.S. courts generally have rejected efforts to circumvent the availability of domestic immunity for foreign officials by reference to international human rights law. Instead, they have treated questions of immunity as controlled by domestic law, and they have in a number of cases applied such immunity to alleged human rights abuses. The limited and targeted congressional interventions in this area only confirm the propriety of this approach.

\section{Back to Pinochet}

The U.S. practice with respect to domestic immunities in civil suits alleging human rights abuses confirms that "[w]hether and how the United States wishe[s] to react to [international law claims raised in its domestic courts] are domestic questions."143 This point has special force in the context of civil human rights litigation, where the ideals of the underlying law clash with the exigencies of international politics. The federal political branches have resolved this tension largely, although not exclusively, in favor of immunities for foreign sovereigns and officials, even for violations of the most serious of international human rights law. Courts have deferred to the political branches on this point, and, as a result, have refused to countenance claims that international human rights law overrides domestic immunities.

The U.S. approach to the relationship between domestic human rights litigation and international immunities differs from the British approach in Pinochet. As noted above, these differences are explained in part by differences in domestic law. Even at a broader level, however, the Pinochet case is not inconsistent with the U.S. approach. As several Law Lords acknowledged, there are important functional differences between immunity in the criminal extradition context and immunity in the context of civil litigation. ${ }^{144}$ Whether in the civil or criminal context, one nation's examination of the validity of another nation's human rights record directly implicates international relations. In the criminal extradition or prosecution context, however, the executive branch has the duty, expertise, and discretion to accommodate such foreign relations

143. Hilao v. Marcos, 25 F.3d 1467, 1475 (9th Cir. 1994) (internal citations and quotations omitted).

144. As Lord Millett noted, there is "nothing illogical or contrary to public policy in denying the victims of state sponsored torture the right to sue the offending state in a foreign court while at the same time permitting (and indeed requiring) other states to convict or punish the individuals responsible if the offending state declines to take action." Second Law Lords' Decision, [1999] 2 W.L.R. 827, 914 (H.L.) (Lord Millett); see also [1999] 2 W.L.R. at 892, 899 (Lord Hutton), 916 (Lord Phillips). 
concerns. By contrast, civil human rights litigation is under the control of private plaintiffs, many of whom are noncitizens, and unelected judges. In this context, a broader and more rule-like approach to immunity doctrine makes sense. Otherwise U.S. foreign relations decision-making would in effect be delegated to foreign human rights victims and federal courts. However noble the aims of international human rights litigation, these actors are not well suited to assess U.S. foreign relations interests. ${ }^{145}$

In this regard, it is worth recalling that the Law Lords expressly encouraged Britain's Home Secretary to reconsider his decision to allow extradition proceedings against Pinochet to go forward, even though the Law Lords had determined that there was a valid legal basis to proceed with extradition. In other words, they understood that their decision would not be the final word on Pinochet's extradition, and they believed that, even if the case for extradition were legally sufficient, it might be outweighed by political considerations. The Home Secretary ultimately ruled that the extradition should proceed. His decision, however, was based on just the sort of balancing of legal and political considerations-including the likely effect of extradition on Great Britain's relations with Chile and on Chile's internal stability-that is not available in private civil litigation. ${ }^{146}$ Because of the unavailability of such a balancing process, it is not surprising that the political branches would impose stricter limits in this context on the extent to which international human rights law developments can override domestic immunities. ${ }^{147}$

\section{Head-of-State ImMunity and the Domestic Status of CUSTOMARY INTERNATIONAL LAW}

The Law Lords' use of international law to limit domestic immunities is not the only way in which the Pinochet decision is relevant to international human rights litigation in U.S. courts. It also is relevant to the claim, often made in this litigation, that CIL is self-executing federal common law, to be "applied by courts in the United States without any need for it to be enacted or implemented

145. It is important to keep in mind that the United States is unique in the extent to which it permits civil international human rights litigation between foreign parties. See Ralph G. Steinhardt, Fulfilling the Promise of Filartiga: Litigating Human Rights Claims Against the Estate of Ferdinand Marcos, 20 YALE J. INTL. L. 65, 101 (1995); Beth Stephens, Litigating Customary International Human Rights Norms, 25 GA. J. INTL. \& CoMP. L. 191, 200 (1996).

146. See supra text accompanying note 44.

147. In Part V, we discuss more generally the United States' resistance to the incorporation of international human rights law into the U.S. legal system. 
by Congress."148 This claim, which we have termed the "modern position," 149 has been central to the success of human rights litigation in U.S. courts because it allows for the judicial incorporation of international human rights law without the need for express political branch approval. At first glance, the modern position resembles the British rule, referred to by some of the Law Lords in Pinochet, that the law of nations is incorporated into the domestic common law. ${ }^{150}$ In addition, proponents of the modern position have invoked the example of head-of-state immunity, which was at issue in Pinochet, as a particularly compelling confirmation of the modern position.

We have extensively critiqued the modern position in other writings. ${ }^{151}$ In this Part, we use the head-of-state immunity example to further develop our critique. As we explain, U.S. courts historically did apply something akin to the British rule of automatic incorporation of CIL, but that regime did not survive Erie $v$. Tompkins. ${ }^{152}$ Instead, courts after Erie have applied CIL rules, including CIL rules of immunity, only when and to the extent they believe they are authorized to do so by the federal political branches. The failure of courts to embrace the modern position in the immunity context, where it would seem to be most justified, casts substantial doubt on the claim that it allows for the judicial incorporation of international human rights law. As a result, instead of confirming the modern position, as its proponents have maintained, the example of head-of-state immunity actually weakens the case for it.

148. Louis Henkin, International Law as Law in the United States, 82 Mrch. L. Rev. 1555, 1561 (1984) [hereinafter International Law as Law].

149. See Curtis A. Bradley \& Jack L. Goldsmith, Customary International Law as Federal Common Law: A Critique of the Modern Position, 110 Harv. L. Rev. 815, 815 (1997) [hereinafter $A$ Critique]. As we have explained, the modern position is appropriately described as "modern" because it was embraced in a judicial decision for the first time in 1980, see Filartiga v. Pena-Irala, 630 F.2d 876, 885 (2d Cir. 1980), and has risen to academic orthodoxy only since that decision, see Bradley \& Goldsmith, supra, at 831-37.

150. See Second Law Lords' Decision, [1999] 2 W.L.R. at 912 (Lord Millett) ("Customary international law is part of the common law ...."); Heathfield v. Chilton, 98 Eng. Rep. 50, 50 (K.B. 1767); 4 William Blackstone, Commentaries *67. The "law of nations" is the traditional term for customary international law.

151. See Bradley \& Goldsmith, A Critique, supra note 149; Bradley \& Goldsmith, The Current Illegitimacy, supra note 88; Curtis A. Bradley \& Jack L. Goldsmith, Federal Couris and the Incorporation of International Law, 111 HARv. L. REv. 2260 (1998) [hereinafter Federal Courts].

152. Erie Railroad Co. v. Tompkins, 304 U.S. 64 (1938). 


\section{A. Head-of-State Immunity and Erie}

To understand the significance of the head-of-state immunity practice for the modern position debate, it is important first to understand how U.S. courts traditionally applied CIL rules of immunity, and how Erie v. Tompkins altered this practice. For most of our nation's history, head-of-state immunity was viewed as a component of foreign sovereign immunity. ${ }^{153}$ Prior to Erie, federal and state courts alike applied the CIL of foreign sovereign immunity on the domestic plane without authorization from Congress or the Executive. Thus, for example, in the 1812 Schooner Exchange decision, the Supreme Court applied the CIL of sovereign immunity without bothering to consider domestic authorization to do so. ${ }^{154}$ Similarly, in Hatch v. Baez, ${ }^{155}$ a New York court relied on an English precedent but no domestic authorization in holding that the former President of the Dominican Republic was entitled to immunity for his official acts.

In these and other cases, state and federal courts applied CIL immunities as part of the "general" common law most famously associated with Swift v. Tyson. ${ }^{156}$ As a form of general common law, the CIL immunities were available as a source of law in domestic litigation. But this CIL did not have the status of federal law and thus had few implications beyond its use in particular decisions. State courts were not bound by federal court determinations of the content of this CIL or the procedures by which it was identified..$^{157}$ The Supreme Court could not review state court interpretations of the CIL of international immunity because such interpretations were not matters of federal law. ${ }^{158}$ And, although state and federal courts were bound by the Executive's determination of whether to recognize a foreign government, they interpreted the $\mathrm{CIL}$ of inter-

153. See Schooner Exchange v. McFaddon, 11 U.S. (7 Cranch) 116, 137 (1812); RESTATEMENT (SECOND) OF FOREIGN ReLATIONS LAW $\S 66$ (1965); Peter D. Trooboff, Foreign State Immunity: Emerging Consensus on Principles, 200 RecueIL DES COURS 235, 252 (1986 V).

154. See Schooner Exchange, 11 U.S. at 147.

155. 14 N.Y. Sup. Ct. 596, 600 (1876).

156. 41 U.S. (16 Pet.) 1 (1842).

157. See G. Edward White, The Transformation of the Constitutional Regime of Foreign Relations, 85 VA. L. REv. 1, 27-28 (1999); see also QuinCY WrIGHT, ThE CONTROL OF AMERICAN Foreign Relations 161 (1922) (noting that a "state constitution or legislative provision in violation of customary international law is valid unless in conflict with a Federal constitutional provision or an act of Congress").

158. See Wulfsohn v. Russian Socialist Federated Republic, 266 U.S. 580, 580 (1924); Oliver American Trading Co. v. Mexico, 264 U.S. 440, $442-43$ (1924); New York Life Ins. Co. v. Hendren, 92 U.S. 286, 286-87 (1875). 
national immunity independent of the views of the executive branch. ${ }^{159}$

During the pre-Erie period, then, U.S. courts, in applying CIL rules of immunity, followed something akin to the British automatic incorporation rule. Erie's abrogation of general common law, and its insistence that all law applied by federal courts be grounded in the Constitution or a federal enactment, called this practice into question. Proponents of the modern position assert that after Erie, the automatic incorporation rule continued but that CIL assumed the status of self-executing federal common law rather than general common law. ${ }^{160}$ If this assertion were correct, one would expect to see courts embracing the modern position in the many international immunity cases decided in the years following Erie. But that is not what happened. Instead, around the time of Erie, the Supreme Court stopped applying the CIL of immunity on its own authority, as it had done under the general common law regime, and began to justify its application on the basis of executive branch authorization. ${ }^{161}$ The law so applied was, to be sure, federal law. It was federal law by virtue of a political-branch authorization, however, and not an independent judicial power to incorporate CIL.

The trend away from the automatic incorporation of CIL immunity principles as nonfederal law to the authorized application of these principles as federal law began the year Erie was decided. In The Navemar, ${ }^{162}$ decided just three months before Erie and issued the day Erie was argued, the Court intimated for the first time that courts were bound by executive suggestions of immunity. ${ }^{163}$ Subsequently, in its 1943 Ex parte Republic of Peru ${ }^{164}$ decision, the Court squarely held that, because immunity determinations implicated im-

159. See, e.g., Berizzi Bros. v. The Pesaro, 271 U.S. 562, 574 (1926) (granting immunity even though State Department had argued in the lower court that immunity should not be granted); see also White, supra note 157, at 134.

160. See, e.g., Henkin, International Law as Law, supra note 148, at 1561; Harold Hongju Koh, Is International Law Really State Law?, 111 HARv. L. REv. 1824, 1831-33 (1998) [hereinafter State Law].

161. As noted in the House Report accompanying the enactment of the FSIA, "In the early part of this century, the Supreme Court began to place less emphasis on whether immunity was supported by the law and practice of nations, and relied instead on the practices and policies of the State Department." H.R. REP. No. 94-1487, at 8 (1976), reprinted in 1976 U.S.C.C.A.N. 6604, 6606.

162. Compania Espanola de Navigacion Maritima, S.A. v. The Navemar, 303 U.S. 68 (1938) [hereinafter The Navemar].

163. The Court stated that, upon receipt of a suggestion of immunity from the executive branch, it was the "duty" of the courts to grant immunity. See The Navemar, 303 U.S. at 74. For a discussion of how The Navemar constituted a break from prior practice, see White, supra note 157 , at $134-41$.

164. 318 U.S. 578 (1943). 
portant foreign relations interests, courts were bound to follow executive suggestions of immunity. ${ }^{165}$ Two years later, in Republic of Mexico v. Hoffman, ${ }^{166}$ the Court went further, stating that even in the face of executive-branch silence, U.S. courts should look to "the principles accepted by the [executive branch]."167 As a result, the Court explained that "[i]t is ... not for the courts to deny an immunity which our government has seen fit to allow, or to allow an immunity on new grounds which the government has not seen fit to recognize."168 These Supreme Court decisions formed the basis for the lower courts' consistent post-Erie, pre-FSIA practice of relying on executive branch guidance and principles to justify the domestic application of sovereign immunity. ${ }^{169}$

The Supreme Court never expressly tied its shift in treatment of foreign sovereign immunity doctrines to Erie. But the shift took place at approximately the same time as Erie, and it is easy to understand why Erie was pivotal. Before Erie, the automatic application of CIL as general common law had relatively few constitutional implications: it did not supersede state law or affect state court practice; it did not create a new basis for federal jurisdiction; and it did not bind the Executive. Once Erie eliminated this form of law in our constitutional system, however, federal courts could apply CIL on their own authority only as federal common law, with more serious constitutional consequences. If CIL were self-executing

165. See 318 U.S. at 588-89.

166. 324 U.S. 30 (1945).

167. Hoffman, 324 U.S. at 35.

168. Hoffman, 324 U.S. at 35.

169. See, e.g., Isbrandtsen Tankers, Inc. v. President of India, 446 F.2d 1198, 1200 (2d Cir. 1971); Heaney v. Spain, 445 F.2d 501, 503 (2d Cir. 1971); Victory Transport, Inc. v. Comisaria General de Abastecimientos y Transportes, 336 F.2d 354, 358-59 (2d Cir. 1964). See generally Monroe Leigh, Sovereign Immunity - The Case of the "Imias," 68 AM. J. INTL. L. 280, 281 (1974); Andreas F. Lowenfeld, Litigating a Sovereign Immunity Claim - The Haiti Case, 49 N.Y.U. L. REv. 377, 389-90 (1974). The lower courts deferred to the Executive even when its suggestions were not consistent with CIL. See Leigh, supra, at 281 (citing Rich v. Naviera Vacuba, S.A., 295 F.2d 24 (4th Cir. 1961) and Chemical Natural Resources, Inc. v. Venezuela, 215 A.2d 864 (1966)). In cases in which the Executive made no suggestion of immunity, several courts stated that the matter was for "judicial determination." See, e.g., Flota Maritima Browning de Cuba v. Motor Vessel Ciudad de la Habana, 335 F.2d 619, 623 (4th Cir. 1964); National Am. Corp. v. Federal Republic of Nigeria, 420 F. Supp. 954, 956 (S.D.N.Y. 1976); Aerotrade, Inc. v. Republic of Haiti, 376 F. Supp. 1281, 1282-83 (S.D.N.Y. 1974); Anaconda Co. v. Corporacion del Cobre, 55 F.R.D. 16, 18 (S.D.N.Y. 1972). But these determinations were always guided by the State Department's policies as articulated in the Tate letter, see infra note 174 and accompanying text, and "several cases ... . used the State Department's failure to intercede after being asked to do so as one basis for denial of immunity," Lowenfeld, supra, at 390. See also Verlinden B.V. v. Central Bank of Nigeria, 461 U.S. $480,487-89$ (1983) (noting that when foreign nations did not seek immunity from the executive branch, "the responsibility feil to the courts to determine whether sovereign immunity existed, generally by reference to prior State Department decisions"). 
U.S. federal common law, then it would provide a basis for "arising under" federal jurisdiction under Article III, supersede inconsistent state law under Article VI, and might bind the President under Article II's "take care" clause. ${ }^{170}$ Especially in the absence of any apparent constitutional authorization for the federalization of CIL, it is not surprising that courts would seek political-branch authorization before embracing these changes in the domestic significance of CIL. As we have just seen, this is precisely what happened in the immunity context. ${ }^{171}$

This posture was especially appropriate because, at the time of Erie, the CIL of immunity was in the midst of a transformation that rendered it less amenable to independent judicial determination. During the nineteenth century, the United States, like many other countries, adhered to the "absolute" theory of sovereign immunity, under which foreign governments were entitled to immunity for essentially all of their acts, even those that were purely commercial in nature. ${ }^{172}$ In the early twentieth century, however, a number of countries began embracing the "restrictive" theory, under which foreign governments were entitled to immunity for their public or sovereign acts, but not for their private or commercial acts. ${ }^{173}$ This shift to the restrictive theory, formally endorsed by the U.S. State Department in $1952,{ }^{174}$ made the CIL of immunity much more complex and difficult to apply. ${ }^{175}$ It also meant that foreign sovereigns

170. For a discussion of these implications, see Bradley \& Goldsmith, A Critique, supra note 149 , at $838-48$.

171. A similar shift took place in the context of the act of state doctrine. This doctrine traditionally was justified by reference to the international law principle of sovereign equality. See supra note 132. As we have just seen, however, Erie rendered problematic the automatic incorporation of international law doctrines. It is thus no surprise that, at about the time of Erie, the Supreme Court began to reconceptualize the doctrine increasingly in domestic law terms. In both United States v. Belmont, 301 U.S. 324, 328-30 (1937) and United States v. Pink, 315 U.S. 203, 229-33 (1942), the Court grounded the doctrine not only in sovereign equality but also in the federal government's, especially the Executive's, broad power over foreign affairs. This reconceptualization culminated in Sabbatino, where the Supreme Court eschewed the international law basis for the doctrine altogether, justifying it solely in terms of separation of powers. By grounding the doctrine in such "'constitutional' underpinnings," Banco Nacional de Cuba v. Sabbatino, 376 U.S. 398, 423 (1964), the Court provided a basis for concluding that there was domestic authorization to treat the doctrine as federal common law. See Bradley \& Goldsmith, A Critique, supra note 149, at 859-61.

172. See Gamal Moursi Badr, State Immunity: An Analytical and Prognostic VIEw 9-20 (1984) (outlining the pre-20th century history of the doctrine in the United States).

173. See id. at 21-62 (describing the transition from absolute to restrictive immunity).

174. See Letter from Jack B. Tate, Acting Legal Advisor, to Philip B. Perlman, Acting Attorney General (May 19, 1952), in 26 DEPT. ST. Bull. 984, 984-85 (1952).

175. See Andreas F. Lowenfeld, Claims Against Foreign States - A Proposal for Reform of United States Law, 44 N.Y.U. L. Rev. 901, 906-09 (1969); Lowenfeld, Litigating a Sovereign Immunity Claim, supra note 169 , at 384. 
would be hailed into court more often, thereby heightening the foreign policy stakes associated with immunity determinations. ${ }^{176}$ In this environment, it made sense that unelected judges with no foreign relations expertise would seek political-branch guidance on whether and how to apply foreign sovereign immunity. ${ }^{177}$

\section{B. Modern Practice}

It does not follow from the above analysis that case-by-case executive-branch authorization is the optimal process for the domestic incorporation of international immunities. This process was, among other things, politicized and unpredictable, ${ }^{178}$ and dissatisfaction with it eventually led Congress in 1976 to enact the FSIA. ${ }^{179}$ In effect, the FSIA transferred the political branch authorization for judicial application of foreign sovereign immunity from executive suggestion to congressional statute. The FSIA does not specify whether its immunities extend to heads of state, either current or former. ${ }^{180}$ The FSIA defines "foreign state" to include a "political subdivision" or an "agency or instrumentality" of a foreign state, ${ }^{181}$ but neither the statute nor its legislative history mentions head-ofstate immunity. ${ }^{182}$

This silence raises the question of whether a foreign head of state is entitled to immunity in U.S. courts after the FSIA, and if so,

176. The Supreme Court had acknowledged the foreign policy implications of exposing foreign sovereigns to suit in Mexico v. Hoffman, 324 U.S. 30, 35-36 (1945).

177. Cf. Lawrence Lessig, Erie-Effects of Volume 110: An Essay on Context in Interpretive Theory, 110 HARv. L. REv. 1785 (1997) (giving general theoretical account of why judges seek political branch authorization when judicial practices become political or controversial).

178. See Lowenfeld, supra note 175, at 909, 913; Frederic Alan Weber, The Foreign Sovereign Immunities Act of 1976: Its Origin, Meaning and Effect, 3 YALE STUD. WORLD Pub. ORD. 1, 11-13, 15-17 (1976).

179. See Verlinden B.V.v. Central Bank of Nigeria, 461 U.S. 480, 486-89 (1983); GARY B. Born, International Civil Litigation In United States Courts 210-11 (3d ed. 1996).

180. Mark Feldman, a participant in the drafting of the FSIA, explained the statute's silence on the head-of-state immunity issue as follows: "Frankly, we forgot about it [head-ofstate immunity], or didn't know enough about it at the time, during those two or three critical years when the statute was being formulated." Panel, Foreign Governments in United States Courts, 85 AM. Socy. INTL. L. PROC. 251, 276 (1991) (remarks of Mark Feldman during panel discussion). By contrast, the sovereign immunity statutes in a number of other countries, including Australia, Canada, and of course Britain, expressly refer to head-of-state immunity. See Foreign States Immunities Act 1985, No. 196, chs. 3(3)(b), 36 (1985) (Austr.), reprinted in 25 I.L.M. 715; Act to Provide for State Immunity in Canadian Courts, 1982, R.S.C., ch. 95 (1982), reprinted in 21 I.L.M. 798; State Immunity Act 1978, ch. 33 (1978) (Eng.), reprinted in 17 I.L.M. 1123.

181. 28 U.S.C. $\S 1603$ (a) (1994). The FSIA's definition of "agency or instrumentality" does not appear to encompass natural persons, since it refers to "any entity . . . which is a separate legal person, corporate or otherwise." \$1603(b) (emphasis added).

182. See Jerrold L. Mallory, Note, Resolving the Confusion Over Head of State Immunity: The Defined Rights of Kings, 86 CoLum. L. REv. 169, 174 (1986). 
on what basis. If the modern position were correct, the basis would be easy to find: head-of-state immunity, as part of CIL, would apply automatically as federal common law, notwithstanding the absence of political branch authorization. In fact, however, of the many decisions in which courts have considered and applied headof-state immunity since enactment of the FSIA, not a single one has applied head-of-state immunity as self-executing CIL. To the contrary, consistent with the post-Erie requirement that all federal common law be authorized by the Constitution or enacted federal law, these courts continue to seek authorization from the political branches to apply head-of-state immunity.

Some courts, for example, view the FSIA as providing for headof-state immunity, even though the text of the statute is silent on the issue. ${ }^{183}$ Other courts view the FSIA as inapplicable to a head of state and instead look to executive branch authorization to apply the doctrine. ${ }^{184}$ Among the courts that seek executive branch authorization, some recognize head-of-state immunity only in the face of an explicit suggestion of immunity by the Executive. ${ }^{185}$ Others rely on the lack of an executive branch suggestion simply as a factor weighing against immunity. ${ }^{186}$ Importantly, in all of these cases, courts ground head-of-state immunity in a federal political branch authorization. ${ }^{187}$ Contrary to the modern position, courts in

183. See, e.g., O'Hair v. Wojtyla, No. 79-2463 (D.D.C. Oct. 3, 1979), excerpted in State Territory, Jurisdiction, and Jurisdictional Immunities, 1979 DIGEST $\$ 7$, at 897 . More generally, a number of courts have construed the FSIA to confer immunity on individual officials. See supra note 99 and accompanying text.

184. See, e.g., United States v. Noriega, 117 F.3d 1206, 1212 (11th Cir. 1997); Lafontant v. Aristide, 844 F. Supp. 128, 137 (E.D.N.Y. 1994); Kilroy v. Windsor, No. C78-291 (N.D. Ohio Dec. 7, 1978), excerpted in State Representation, 1978 DigEST § 3, at 641-43.

185. See, e.g., Jungquist v. Nahyan, 940 F. Supp. 312, 321 (D.D.C. 1996).

186. See, e.g., First American Corp. v. Al-Nahyan, 948 F. Supp. 1107, 1121 (D.D.C. 1996); cf. Noriega, 117 F.3d at 1212 (inferring absence of immunity for Manuel Noriega from executive branch's enforcement action against Noriega in Panama). Estate of Domingo v. Marcos provides a good illustration of the extent of executive control in this area. See Estate of Domingo v. Marcos, No. C82-1055-V (W.D. Wash. Dec. 23, 1982), excerpted in State Territory, Jurisdiction, and Jurisdictional Immunities, 2 Cumulative Digest 1981-1988 § 7, at 1564-66 (1995). The court initially granted immunity to Ferdinand Marcos based on an executive suggestion. Subsequently, the Executive changed its position and suggested a denial of immunity, and the court then followed that suggestion. See Estate of Domingo, No. C821055-V, in 2 Cumulative Digest, supra, at 1568-69. Compare Estate of Domingo v. Republic of the Philippines, 694 F. Supp. 782, 786 (W.D. Wash. 1988) (denying immunity to Marcos and noting that "although the State Department filed a suggestion of immunity when Marcos was president, it has not filed a new suggestion of immunity") with Psinakis v. Marcos, No. C75-1725-RHS (N.D. Cal. 1975), excerpted in State Territory, Jurisdiction, and Jurisdictional Immunities, 1975 DIGEST $\$ 7$, at 344-45 (honoring a suggestion of immunity for then-President Marcos).

187. But cf. In re Doe, 860 F.2d 40, 45 (2d Cir. 1988) (stating in dicta that "[w]hen lacking guidance from the executive branch, as here, a court is left to decide for itself whether a head-of-state is or is not entitled to immunity"). 
this context do not assume that the CIL of head-of-state immunity applies as self-executing federal common law.

\section{Significance for Human Rights Litigation in U.S. Courts}

This account of the way in which courts have treated head-ofstate immunity has important implications for the broader debate over the legitimacy of the modern position and, as a result, over the legitimacy of international human rights litigation in U.S. courts. The modern position has been central to this litigation for two reasons. The first is a technical but important jurisdictional point. The typical international human rights lawsuit involves a foreign plaintiff suing a foreign official in U.S. court for human rights abuses that took place on foreign soil. The plaintiff usually sues under the ATS, which, as noted above, states that the federal district courts shall have jurisdiction over any civil action "by an alien for a tort only, committed in violation of the law of nations or a treaty of the United States."188 The Article III basis for alien-versus-alien human rights cases is uncertain, however, because the parties are not diverse, ${ }^{189}$ and the plaintiffs do not (for reasons explained below) seek relief under a treaty. ${ }^{190}$ Here is where the modern position comes in, because if CIL is federal common law, then ATS suits can plausibly be viewed as "arising under" federal law for purposes of Article III. This indeed was the holding of the Filartiga decision that initiated the modern human rights litigation movement. 191

The second reason the modern position is important to human rights litigation concerns substantive law. Most of the principles of international human rights law invoked in domestic litigation are contained in multilateral treaties. ${ }^{192}$ U.S. courts cannot apply these treaties, however, for two reasons. First, the United States has failed to ratify a number of them. ${ }^{193}$ Second, when the United

188. 28 U.S.C. $\$ 1350$ (1994).

189. The Supreme Court has long held that alien-versus-alien suits do not fall within Article III's diversity clause. See, e.g., Hodgson v. Bowerbank, 9 U.S. (5 Cranch) 303, 304 (1809).

190. Article III includes within its categories of federal judicial power "Cases, in Law and Equity, arising under . . Treaties." U.S. ConsT. art. III, \& 2, cl. 1.

191. See Filartiga v. Pena-Irala, 630 F.2d 876, 885 (2d Cir. 1980).

192. See, e.g., Louis Henkin, International Law: Polmtics and Values 36 (1995) [hereinafter PoLrTICs AND VALUEs]; Louis B. Sohn, The New International Law: Protection of the Rights of Individuals Rather Than States, 32 AM. U. L. REv. 1, 12 (1982).

193. For example, the United States has not ratified either the Convention on the Rights of the Child, adopted Nov. 20, 1989, B.T.S. 44 (1992), cm. 1976 (Eng.), 28 I.L.M. 1448, or the Convention on the Elimination of All Forms of Discrimination Against Women, adopted Dec. 18, 1979, 1249 U.N.T.S. 13. 
States has ratified human rights treaties, it has insisted, through a series of reservations, understandings, and declarations (RUDs), that the treaties cannot be used as a source of law in domestic litigation. ${ }^{194}$ The modern position provides a way for courts to apply the norms in these treaties as domestic law despite this political branch resistance because, through a process that remains obscure and controversial, human rights treaties are viewed as giving rise to an independently valid CIL of human rights. ${ }^{195}$ Under the modern position, this treaty-derived CIL can be applied as domestic law in human rights cases even though the treaties themselves cannot be applied domestically either because of lack of ratification or because of the RUDs. In this way, the modern position "compensate[s] for the abstinence of the United States vis-à-vis ratification of international human rights treaties."196

Some of the problems with the modern position are apparent from this description of the relationship between the CIL of human rights and human rights treaties. ${ }^{197}$ It is generally accepted that federal common law must be authorized in some fashion by the Constitution or federal statute, and that federal common law is defined and limited by the actions of the federal political branches. ${ }^{198}$ As a result, it seems illegitimate for federal courts to apply as domestic law a CIL of human rights based almost exclusively on human rights treaties that the political branches have taken pains to ensure do not apply as domestic law. Such a federal common law seems especially inappropriate because other federal enactments

194. See generally Louis Henkin, U.S. Ratification of Human Rights Conventions: The Ghost of Senator Bricker, 89 AM J. INTL. L. 341 (1995) [hereinafter Ghost of Senator Bricker]; David P. Stewart, United States Ratification of the Covenant on Civil and Political Rights: The Significance of the Reservations, Understandings, and Declarations, 42 DEPAUL L. REV. 1183 (1993).

195. For endorsements of this process, see HENKIN, PolmTics AND VAlues, supra note 192, at 37-44; Richard B. Lillich, The Constitution and International Human Rights, 83 AM. J. INTL. L. 851, 856-58 (1989); Louis B. Sohn, The New International Law: Protection of the Rights of Individuals Rather than States, 32 AM. U. L. REv. 1, 12 (1982). For criticism, see Simma \& Alston, supra note 67; J.S. Watson, Legal Theory, Efficacy and Validity in the Development of Human Rights Norms in International Law, 1979 U. ILL. LEGAL F. 609.

196. Simma \& Alston, supra note 67, at 87; see also Lillich, supra note 195 , at $856-57$ (making a similar point); Bradley \& Goldsmith, Federal Courts, supra note 151 (same).

197. For a more comprehensive analysis of these problems, see Bradley \& Goldsmith, $A$ Critique, supra note 149.

198. See D'Oench, Duhme \& Co. v. Federal Deposit Ins. Corp., 315 U.S. 447, 472 (1942) (Jackson, J., concurring) ("[F]ederal common law implements the Federal Constitution and statutes, and is conditioned by them."); Erie Railroad Co. v. Tompkins, 304 U.S. 64, 78 (1938) ("Except in matters governed by the Federal Constitution or by Acts of Congress, the law to be applied in any case is the law of the State."). See generally Larry Kramer, The Lawmaking Power of the Federal Courts, 12 PACE L. REv. 263, 286-88 (1992). 
indicate political branch resistance to a wholesale federal incorporation of international human rights. ${ }^{199}$

When attempting to justify the modern position, its proponents tend not to address these separation of powers objections to the automatic judicial incorporation of CIL. They concentrate instead on federalism objections, which they dismiss because of a purported need for national uniformity in foreign affairs. In addition, they avoid emphasizing international human rights law issues, such as the death penalty, because such issues implicate traditional state prerogatives and thus are difficult to justify as an exclusive federal concern. They instead point to traditional CIL governing relations between nations, which appears to trigger an exclusive federal prerogative and thus seems easier to justify as an exercise of federal common law. In particular, recent defenses of the modern position have rested heavily on the example of the CIL of immunity.

Consider, for example, Harold Koh's recent defense of the modern position. ${ }^{200}$ Koh reasoned that if CIL did not apply automatically as domestic federal law, "Massachusetts [could] deny the customary international law protection of head-of-state immunity to Queen Elizabeth on tort claims arising out of events in Northern Ireland, whereas the forty-nine other states could choose instead to grant the Queen every conceivable variant of full or partial immunity." ${ }^{201}$ Koh similarly suggested that rejection of the modern position would mean that "federal judges sitting in New York diversity actions filed against Imelda Marcos, Lee Teng-hui, Benjamin Netanyahu, Yasser Arafat, or Pope John Paul II would have to guess whether the New York Court of Appeals would accord each or all of these defendants head-of-state immunity."202 Koh concluded from these examples that it is "radical" and "bizarre" to question the proposition that CIL has the status of federal law. ${ }^{203}$

Two points are worth noting regarding Koh's use of the head-ofstate immunity example to justify the modern position. First, the example is misleading to the extent that it suggests that the modern position is necessary in order to ensure state compliance with traditional CIL. In fact, the modern position is not needed for this purpose because the political branches have already codified by treaty

199. See supra text accompanying notes 133-42. For further discussion, see infra Part V. 200. See Koh, State Law, supra note 160; see also Harold Hongju Koh, The 1998 Frankel Lecture: Bringing International Law Home, 35 Hous. L. Rev. 623 (1998).

201. Koh, State Law, supra note 160, at 1829.

202. Id. at 1850.

203. See id. at 1828,1850 . 
or statute almost all of the traditional CIL that is relevant to domestic litigation, rendering traditional CIL practically irrelevant as a rule of decision or defense in domestic litigation. Head-of-state immunity is a truly exceptional example of a traditional CIL norm potentially relevant to domestic litigation that is not expressly codified in enacted federal law. ${ }^{204}$

Second, and more importantly, courts apply head-of-state immunity in a fashion that is inconsistent with the modern position. They ground the application of head-of-state immunity in authorization by the political branches, usually the Executive. Modern position proponents invoke the head-of-state immunity example because it is a traditional rule of $\mathrm{CIL}$ that directly implicates relations with foreign nations and thus presents the best possible context in which to justify the modern position. But courts do not, in fact, embrace the modern position even in this most favorable of contexts. Instead, they seek political-branch authorization to apply CIL, and they take care to ensure that the law so applied conforms to the policies of the political branches. To return to one of Koh's examples, rejection of the modern position does not mean that courts would deny head-of-state immunity protection to the Queen of England. It simply means that they would not confer such immunity directly under CIL, but rather would do so in accordance with the wishes of the executive branch, which has the lead role in conducting U.S. foreign policy with England.

This practice has important implications for the claim that a CIL of human rights applies as domestic federal law even in the absence of political-branch authorization. The CIL of human rights is more difficult to defend than traditional CIL as an area of federal common law. Unlike traditional CIL, the CIL of human rights overlaps substantially with traditional state prerogatives and thus should be federalized, if at all, only by the democratically elected federal political branches where state interests are represented. ${ }^{205}$ More-

204. Gerald Neuman contends that another such example is consular immunity. See Gerald L. Neuman, Sense and Nonsense About Customary International Law: A Response to Professors Bradley and Goldsmith, 66 Fordham L. Rev. 371, 377 n.37, 382, 391 (1997). CIL rules governing consular immunity, however, have been codified in the Vienna Convention on Consular Relations, Apr. 24, 1963, 21 U.S.T. 77, 596 U.N.T.S. 261, a multilateral treaty that has been ratified by most nations of the world, including the United States. See United Nations, United Nations Treaty Collection, Multilateral Treaties deposited with the Secretary General, Chapter 3 (visited June 14, 1999) <http://www.un.org/Depts/Treaty> (registration required) (reporting that 163 nations had ratified this treaty as of June 1999). Since the U.S. ratification of the Convention in 1969, there has not been a single case in U.S. courts involving the CIL of consular immunity.

205. See Thomas Merrill, The Common Law Powers of Federal Courts, 52 U. CHI. L. REv. 1, 17 (1985) (explaining why "[f]ederal courts . . . should not promulgate federal com- 
over, the political branches have affirmatively resisted the wholesale judicial incorporation of the CIL of human rights. ${ }^{206}$ As a result, the modern position seems especially questionable in the context in which it most matters - international human rights litigation.

The questionable basis for the modern position in the human rights context presents a puzzle. Why would courts embrace the modern position in the substantive human rights law context but not in the head-of-state immunity context, given that the justifications for the practice seem weaker in the former? The puzzle is solved when one sees that, contrary to academic assertions and judicial dicta, courts for the most part have not embraced the modern position with respect to the CIL of human rights.

The decisions that come closest to embracing the proposition that a CIL of human rights applies as self-executing federal common law are in human rights cases litigated under the ATS. The watershed case, Filartiga, definitely relied on this proposition in upholding the constitutionality of the ATS.207 While later cases often repeat this proposition in dicta, they tend to apply a CIL of human rights in a fashion that is consistent with the political-branch authorization requirement. For example, in the large majority of successful international human rights cases, courts hold that Congress in the ATS created a domestic federal cause of action for violations of the CIL of human rights. ${ }^{208}$ Less often, courts hold that Congress in the ATS authorized courts to develop a CIL of federal common law. ${ }^{209}$ Some commentators have challenged these interpretations of the ATS. ${ }^{210}$ The pertinent point for now, however, is that, rightly or wrongly as a matter of statutory interpretation, courts view the ATS as having authorized the incorporation of CIL into domestic law.

mon law rules that intrude upon [the traditional domain of the states] unless they have been authorized to do so by an enacting body in which the states are represented").

206. See supra text accompanying notes 133-42, 194; see also infra Part V.

207. See supra text accompanying notes $91,189-91$.

208. See, e.g., Hilao v. Marcos, 25 F.3d 1467, 1475 (9th Cir. 1994); Trajano v. Marcos, 978 F.2d 493, 503 (9th Cir. 1991); Xuncax v. Gramajo, 886 F. Supp. 162, 179-84 (D. Mass. 1995); Paul v. Avril, 812 F. Supp. 207, 212 (S.D. Fla. 1993); Forti v. Suarez-Mason, 672 F. Supp. 1531, 1539-40 (N.D. Cal. 1987); Handel v. Artukovic, 601 F. Supp. 1421, 1426-27 (C.D. Cal. 1985).

209. See Abebe-Jira v. Negewo, 72 F.3d 844, 848 (11th Cir. 1996).

210. See, e.g., Bradley \& Goldsmith, The Current Illegitimacy, supra note 88, at 358-63; Alfred P. Rubin, U.S. Tort Suits by Aliens Based on International Law, InTz. Prac. NoтввоoK, Jan. 1983, at 19, 20-23; Sweeney, supra note 88; see also Tel-Oren v. Libyan Arab Republic, 726 F.2d 774, 811-16 (D.C. Cir. 1984) (Bork, J., concurring). 
Further evidence that courts do not view CIL as federal common law beyond the extent authorized by Congress can be found in judicial resistance to applying a CIL of human rights to domestic officials. If the modern position were correct, courts should apply the ostensible CIL of human rights, like other federal law, to domestic officials. But federal courts do not in fact do so. They defer to congressional statutes that violate customary international human rights law. ${ }^{211}$ They generally do not apply customary international human rights law to limit executive action. ${ }^{212}$ In addition, although there is a widespread academic consensus that the CIL of human rights should override inconsistent state law under the supremacy clause, ${ }^{213}$ U.S. courts have never applied CIL in this fashion, and they show no inclination to do so.

\section{Why Resist the Domestic Incorporation of INTERNATIONAL HUMAN RIGHTS LAW?}

We have argued in this article that the federal political branches have, with limited exceptions, taken steps to limit international human rights litigation in U.S. courts. In particular, they have granted foreign states and their officials broad immunities from suit and they have largely resisted the domestic incorporation of substantive international human rights law. We have further argued that courts should be, and generally have been, faithful to these political branch actions. Why have our elected officials resisted the incorporation of international human rights law into civil litigation? And why do we maintain that federal courts in such litigation should not play an independent role in the incorporation of international human rights norms?

Our answer to these questions is not based on skepticism regarding either the aims of international human rights law or the legitimacy of international law generally. It is instead based on the view that the use of domestic civil litigation to enforce international human rights law raises a number of serious problems for which the

211. See, e.g., Galo-Garcia v. INS, 86 F.3d 916, 918 (9th Cir. 1996); United States v. Yunis, 924 F.2d 1086, 1091 (D.C. Cir. 1991); Garcia-Mir v. Meese, 788 F.2d 1446, 1453 (11th Cir. 1986).

212. See, e.g., United States v. Alvarez-Machain, 504 U.S. 655, 666-70 (1992); Gisbert v. U.S. Attorney Gen., 988 F.2d 1437, 1448 (5th Cir. 1993); Garcia-Mir v. Meese, 788 F.2d 1446, 1453-54 (11th Cir. 1986). But see Fernandez v. Wilkinson, 505 F. Supp. 787, 795, 798 (D. Kan. 1980).

213. See, e.g., Lea Brilmayer, Federalism, State Authority, and the Preemptive Power of International Law, 1994 SuP. CT. REv. 295; Henkin, International Law as Law, supra note 148. 
federal political branches are and should be constitutionally responsible. Those who argue for an open-ended incorporation of international human rights law into domestic civil litigation tend to overlook or discount these problems. In this Part, we consider these problems in two contexts: the application of international human rights law against domestic officials and human rights lawsuits against foreign governmental officials. We conclude by noting several ways in which the Pinochet decision provides support for the United States' general resistance to incorporating international human rights norms into its domestic civil litigation system.

\section{A. Domestic Officials}

The federal political branches have taken significant steps to ensure that international human rights law cannot be applied in civil litigation against U.S. officials. The RUDs attached to the U.S. ratification of human rights treaties render the treaties unenforceable as domestic law.214 On the rare occasion when the political branches authorize the application of international human rights norms in civil litigation, they do so only with respect to foreign officials, not domestic officials. ${ }^{215}$ The political branches have applied international human rights norms to domestic officials for genocide and war crimes, but these prohibitions can be enforced only by the Executive. ${ }^{216}$ Finally, although the modern position contemplates that CIL should be enforceable as federal law against domestic officials, even those courts that embrace the modern position do not in fact apply CIL to domestic officials, state or federal.217

The federal government's disinclination to apply international human rights law to domestic officials has been severely criticized.218 One problem with these criticisms is that they tend to

214. See supra text accompanying note 194 . Even a recent executive order by the Clinton Administration that purports to implement human rights treaties within the federal executive branch makes clear that "[n]othing in this order shall create any right or benefit, substantive or procedural, enforceable by any party against the United States, its agencies or instrumentalities, its officers or employees, or any other person" and that "[ $t]$ his order does not supersede Federal statutes and does not impose any justiciable obligations on the executive branch." Implementation of Human Rights Treaties, Exec. Order No. 13107, 63 Fed. Reg. 68,991, 68,993 (1998).

215. See supra text accompanying notes $134-42$.

216. See Genocide Convention Implementation Act, 18 U.S.C. $\S 1091$ (1988); War Crimes Act of 1996, 18 U.S.C.A. § 2441 (Supp. 1999).

217. See supra notes $211-13$ and accompanying text.

218. See, e.g., Mark Gibney, Human Rights Litigation in U.S. Courts: A Hypocritical Approach, 3 BurF. J. INTL. L. 261 (1997); Henkin, Ghost of Senator Bricker, supra note 194; Kenneth Roth, Side-Lined on Human Rights: American Bows Out, FoREIGN AFF., March/ April 1998, at 2. 
overlook the extraordinary human rights protections the United States offers through its domestic constitutional and democratic processes. The Bill of Rights, the Reconstruction Amendments, and federal and state criminal and civil rights laws broadly prohibit governmental misconduct. It is true, of course, that these domestic legal protections are not always perfectly enforced. For example, many of the U.S. police and prison practices that Amnesty International recently described as violating international law $^{219}$ are equally violative of domestic law. The problem in these contexts is not an absence of law, but rather insufficient enforcement of and compliance with domestic law. This serious and complicated problem is to some extent inevitable in all legal systems. Incorporating international human rights law into domestic law, however, would not redress this problem.

We do not mean to suggest that international human rights law and domestic human rights protections are coextensive. In some instances international human rights law probably recognizes different and more protective rights than those available under U.S. domestic law. When these differences are examined closely, however, the United States' failure to incorporate international human rights norms appears less problematic than critics suggest.

The U.S. Constitution, including the Bill of Rights, requires some of the differences. Thus, for example, the International Covenant on Civil and Political Rights (ICCPR) 220 prohibits racial hate speech, ${ }^{221}$ and the Convention on the Elimination of All Forms of Racial Discrimination ${ }^{222}$ prohibits racist propaganda and requires elimination of racist organizations. ${ }^{223}$ Because such speech and organizations in many instances are protected by the First Amendment, the United States entered reservations refusing to ac-

219. See AMNESTy INTERNATIONAL, Rights For All 17.86 (1998).

220. International Covenant on Civil and Political Rights, adopted Dec. 19, 1966, S. ExEC. Doc. E, 95-2 (1978), 999 U.N.T.S. 171 [hereinafter ICCPR].

221. See id. art. 20(2), S. ExEc. Doc. E, 95-2, at 29, 999 U.N.T.S. at 178 (prohibiting "[a]ny advocacy of national, racial or religious hatred that constitutes incitement to discrimination, hostility or violence").

222. International Convention on the Elimination of All Forms of Racial Discrimination, opened for signature Mar. 7, 1966, S. EXEc. Doc. C, 95-2 (1978), 660 U.N.T.S. 195.

223. See id. art. 4(a), S. ExEc. Doc. C, 95-2, at 3, 660 U.N.T.S. at 220 (requiring nations to punish by law "all dissemination of ideas based on racial superiority or hatred"); id. art. 4(b), S. ExEc. Doc. C, 95-2, at 3-4, 660 U.N.T.S. at 220 (requiring nations to "declare illegal and prohibit," and to punish participation in, organizations that "promote and incite racial discrimination"); $i d$. art. 7, S. ExEC. Doc. C, 95-2, at 5, 660 U.N.T.S. at 222 (requiring nations to "adopt immediate and effective measures, particularly in the fields of teaching, education, culture and information, with a view to combating prejudices which lead to racial discrimination"). 
cept these obligations. ${ }^{224}$ Even in the absence of such reservations, any political branch consent to these norms would be unenforceable as domestic law. 225

Many of the other supposed differences between the requirements of international human rights law and U.S. domestic law are based on tendentious constructions of the relevant human rights norms, constructions made possible by the vague way in which these norms are identified and crafted. This vagueness is in turn a principal reason why the United States does not authorize courts to apply this law against domestic officials.

International human rights law is vague along two dimensions. The first type of vagueness concerns the criteria for identifying the appropriate sources of $\mathrm{CIL}$. Traditionally, a nation was bound under CIL only to the international obligations to which it had implicitly given its consent through customary practice. ${ }^{226}$ As understood by human rights advocates and some courts, modern international human rights law significantly weakens, if not eliminates, these consent and customary practice requirements for CIL. ${ }^{227}$ "Customary" international human rights law does not depend on actual consent or actual practice, but rather depends on an "international consensus" constituted by an uncertain brew of treaty norms (ratified or not), General Assembly resolutions, international commissions, and academic commentators. 228 Thus, for example, some of the Law Lords in the Pinochet decision thought

224. See U.S. Senate Resolution of Advice and Consent to Ratification of the International Convention on the Elimination of All Forms of Racial Discrimination, 140 CONG. REC. 14,326 (1994); U.S. Senate Resolution of Advice and Consent to Ratification of the International Covenant on Civil and Political Rights, 138 Cong. Rec. $8070-71$ (1992). The Genocide Convention too contains a reservation stating that the United States does not accept any obligation prohibited by its Constitution. See U.S. Senate Resolution of Advice and Consent to Ratification of the International Convention on the Prevention and Punishment of the Crime of Genocide, 132 Cong. Rec. 2349 (1986).

225. See Boos v. Barry, 485 U.S. 312, 324 (1988) ("[I]t is well-established that 'no agreement with a foreign nation can confer power on the Congress, or on any other branch of Government, which is free from the restraints of the Constitution."' (quoting Reid v. Covert, 354 U.S. 1, 16 (1957))).

226. See Mark W. Janis, An Introduction to International LaW $42-43$ (3d ed. 1999); see also, e.g., The Paquete Habana, 175 U.S. 677, 700 (1900) (noting that the law of nations is derived in part from "the customs and usages of civilized nations"); The Antelope, 23 U.S. 66, 120-22 (1825) (observing that the law of nations is derived from "the usages, the national acts, and the general assent" of the nations of the world).

227. See Henkin, Politics And Values, supra note 192, at 37-38; Blum \& Steinhardt, supra note 7, at 64-75; Louis B. Sohn, The New International Law: Protection of the Rights of Individuals Rather than States, 32 AM. U. L. REv. 1, 9-10 (1982).

228. See Henkin, Polrtics AND VAlues, supra note 192, at 38; JANIs, supra note 226, at 103-04; Randall, Federal Questions, supra note 6, at 388-93; Steinhardt, supra note 145, at 7981; see also, e.g., Filartiga v. Pena-Irala, 630 F.2d 876, 881-85 (2d Cir. 1980). 
that, based on General Assembly pronouncements and the writings of scholars, CIL prohibited torture long before ratification of the Torture Convention.229 Similarly, many commentators claim that the U.S. practice of executing juvenile offenders for capital crimes violates international law, even though this U.S. practice is longstanding, and the United States has expressly declined to consent to treaties outlawing the practice. ${ }^{230}$

A second type of vagueness exacerbates the uncertainty problem: even when the source of international human rights law is clear, as is the case with application of duly ratified treaties, the content of the norms embodied in the law is often exceedingly vague. Of course, the language of pertinent U.S. constitutional and other protections is sometimes similarly vague. These vague domestic provisions, however, have been given more precise content through hundreds and sometimes thousands of judicial decisions. This large body of interpretive case law certainly does not render the domestic provisions determinant in all contexts. But it does provide a broad core of settled meaning at any particular point in time that sharply contrasts with analogous international provisions.

Consider the Fourth Amendment's prohibition on "unreasonable searches and seizures,"231 which is perhaps a paradigmatic example of an open-ended and indeterminate constitutional provision. Its requirements have changed over time, and when applied in novel contexts it might well provide little if any real guidance. Nonetheless, the Fourth Amendment has been interpreted in thousands of different cases, and these precedents provide police officials at any particular time with significant guidance. ${ }^{232}$ The same cannot be said, for example, of the ICCPR's analogous prohibition on "arbitrary arrest or detention." 233 The Fourth Amendment and the ICCPR provision are similarly vague as writ-

229. See, e.g., Second Law Lords' Decision, [1999] 2 W.L.R. 827, 903 (H.L.) (Lord Saville), 912 (Lord Millett).

230. See, e.g., Joan F. Hartman, "Unusual" Punishment: The Domestic Effects of International Norms Restricting the Application of the Death Penalty, 52 U. CiN. L. Rev. 655 (1983); Julian S. Nicholls, Too Young to Die: International Law and the Imposition of the Juvenile Death Penalty in the United States, 5 EMORY INTL. L. Rev. 617 (1991); David Weissbrodt, Execution of Juvenile Offenders by the United States Violates International Human Rights Law, 3 Am. U. J. INTL. L. \& Poly. 339 (1988).

231. U.S. CoNST. amend. IV.

232. For an overview of what is generally settled in Fourth Amendment jurisprudence, and what is not, see Twenty-Seventh Annual Review of Criminal Procedure, 86 GEo. L.J. $1153,1187-1352$ (1998). 175.

233. See ICCPR, supra note 220 , art. 9(1), S. ExEC. Doc. E, 95-2, at 26, 999 U.N.T.S. at 
ten, but the Fourth Amendment is relatively more determinant in practice because of the judicial precedents interpreting it.

The vague content of international human rights norms places the United States in a difficult position. The aims of international human rights law are often desirable, and it is hard to disagree with the content of much of this law considered in the abstract. If this law were incorporated into the U.S. legal system, however, it could have profound and unforeseen effects on U.S. domestic law. Although the provisions in human rights treaties often appear to be similar to the protections available under U.S. domestic law, they are couched in different terms and it is therefore impossible to predict how these new sources of law would be interpreted and applied by U.S. judges.

This uncertainty is illustrated by examples from the ICCPR, perhaps the most important of all human rights treaties. How would the ICCPR's prohibition on "arbitrary arrest and detention"234 affect the constitutional practice of checkpoint sobriety stops?235 How would its requirement that an arrestee "be brought promptly before a judge" 236 affect the generally constitutional practice of conducting arraignments within 48 hours of arrest? ${ }^{237}$ Would its requirement that every "human being" have an "inherent right to life" that "shall be protected by law"238 strengthen, weaken, or have no effect on otherwise-legal parental notification requirements for juvenile abortions? ${ }^{239}$ Would the ICCPR's guarantee of an "enforceable right to compensation" for "[a]nyone who has been the victim of unlawful arrest or detention"240 override otherwise-legitimate qualified immunity defenses? ${ }^{241}$ How would the requirement that "[a]1l persons deprived of their liberty shall be treated with humanity and with respect for the inherent dignity of

234. See id.

235. See Michigan Dept. of State Police v. Sitz, 496 U.S. 444, 455 (1990) (holding that sobriety checkpoints are legal under the Fourth Amendment).

236. ICCPR, supra note 220, art. 9(3), S. EXEC. Doc. E, 95-2, at 26, 999 U.N.T.S. at 175.

237. See County of Riverside v. McLaughlin, 500 U.S. 44, 58-59 (1991) (holding that Fourth Amendment's "promptness" requirement generally is satisfied by arraignment within 48 hours).

238. ICCPR, supra note 220, art. 6(1), S. ExEc. Doc. E, 95-2, at 25, 999 U.N.T.S. at 174.

239. See Lambert v. Wicklund, 520 U.S. 292, $297-99$ (1997) (upholding constitutionality of certain parental notification requirements).

240. ICCPR, supra note 220, art. 9(5), S. ExEC. Doc. E, 95-2, at 26, 999 U.N.T.S. 176 (emphasis added).

241. See Malley v. Briggs, 475 U.S. 335, 345-56 (1986) (recognizing qualified immunity defense for unlawful arrests). 
the human person"242 affect controversial but constitutional prison practices? ${ }^{243}$ There are scores of similar uncertainties, under both the ICCPR and other human rights treaties.

The vagueness of international human rights law is even more severe in the context of CIL. In that context, there is no text, and no settled list of sources, to guide interpretation. Moreover, as noted above, the objective "state practice" component of CIL has been relaxed in the human rights context. ${ }^{244}$ The open-ended nature of the CIL of human rights is illustrated by the rapidly expanding claims regarding its content. As late as 1986, the Restatement (Third) of the Foreign Relations Law of the United States limited the list of CIL human rights norms to prohibitions against extremely egregious conduct such as torture and genocide. 245 Since that time, commentators have argued that CIL includes a wide range of additional rights, including rights relating to the death penalty, gender violence, and the environment.246 And the list keeps growing. As Ted Meron has observed, "given the rapid continued development of international human rights, the list as now constituted should be regarded as essentially openended. . . . Many other rights will be added in the course of time." 247

The difficulties associated with ascertaining the content of vague human rights norms are heightened by the fact that the body of interpretive materials that will eventually provide this content will not necessarily be based on considerations of U.S. law and policy. The United States has no privileged say regarding how the vague norms of international human rights law will come to be viewed in practice. Such meaning will be determined by the decentralized decisions of a variety of national courts, human rights commissions, other international law bodies, and the writings of scholars. Although these decisions may in some instances comport with the views of U.S. policymakers, there is no guarantee that this will be the case.

242. ICCPR, supra note 220, art. 10(1), S. ExEc. Doc. E, 95-2, at 26, 999 U.N.T.S. at 176.

243. See Patrick J.A. McClain et al., Prisoners' Rights: Substantive Rights Retained by Prisoners, 86 GEO. L.J. 1953, 1953-88 (1998).

244. See supra notes $226-30$ and accompanying text.

245. See Restatement (Third), supra note 5, § 702.

246. See, e.g., Beth Stephens \& Michael Ratner, International Human Rights Litigation IN U.S. Courts 86-94 (1996).

247. Theodor Meron, Human Rights and Humanttarian Norms as Customary LAW 99 (1989). 
This profound uncertainty regarding the actual content of human rights norms gives the United States a legitimate reason not to incorporate international human rights law into domestic law. International law does not require any particular manner of domestic implementation of its obligations, and many nations, including Great Britain, view all treaties as non-self-executing. The United States has taken the position that its obligations under the human rights treaties are fully met by its domestic legal protections, including, sometimes, domestic legislation implementing particular international obligations. This is a perfectly legitimate method of respecting international obligations. It is hard to know for sure, of course, whether U.S. domestic legal protections fully meet the requirements of the vague treaty requirements. This is one reason why the United States, in addition to declaring the human rights treaties to be non-self-executing, attaches understandings that clarify its obligations and narrowly defined reservations that exclude obligations it cannot meet.

This practice is especially understandable given that the United States provides extraordinary - though of course far from perfect - human rights protections through its domestic constitutional and political processes. The United States agrees with many of the obligations in the treaties, at least in the abstract terms in which the obligations are couched; thus it assents to many of these obligations in its ratifications. Because these obligations are so uncertain in practice, however, the United States makes clear that it understands the obligations largely to coincide with United States domestic law and practice, which, at least in comparison, is relatively clear. ${ }^{248}$ This practice does not, as so many commentators claim, show contempt for international law. By ensuring that the United States does not assume international obligations that it is not prepared to comply with, it arguably shows just the opposite.

248. For examples of such statements in connection with U.S. ratification of human rights treaties, see U.S. Senate Resolution of Advice and Consent to Ratification of the International Convention on the Elimination of All Forms of Racial Discrimination, 140 CoNG. REc. 14,326 (1994); U.S. Senate Resolution of Advice and Consent to Ratification of the International Covenant on Civil and Political Rights, 138 CoNG. Rec. 8070-71 (1992); U.S. Senate Resolution of Advice and Consent to Ratification of the Convention Against Torture and Other Cruel, Inhuman or Degrading Treatment or Punishment, 136 CoNG. REC. 36198-99 (1990); U.S. Senate Resolution of Advice and Consent to Ratification of the International Convention on the Prevention and Punishment of the Crime of Genocide, 132 Cong. REc. 2349-50 (1986). 


\section{B. Foreign Officials}

The political branches and the courts have been somewhat more receptive to applying international human rights law against foreign officials. Even in this context, however, the application of international human rights law has been quite limited. Filartiga and its progeny have allowed international human rights lawsuits against foreign officials to proceed under the ATS. As noted above, however, the Supreme Court has made it clear that such ATS suits are limited by foreign sovereign immunity. ${ }^{249}$ In addition, in the few instances in which the political branches have expressly provided for the application of international human rights law against foreign officials - for example, in the Torture Victim Protection Act and the recent terrorism amendments to the FSIA - they sharply limited the types of actions that can be brought, and they also imposed significant procedural limitations on these actions. ${ }^{250}$

At first glance, these limitations seem surprising. The United States has long been a champion of human rights, and it frequently exercises moral, economic, and military pressure against governments perceived as violating those rights. Why, in this light, would the United States resist broad application of international human rights law against foreign officials in U.S. courts?

Part of the answer has to do with fairness concerns implicated by the substantive and procedural vagueness of international human rights law. The norms applied under the Filartiga rubric are generated by the unstructured and open-ended CIL-identification process discussed above. Moreover, the Filartiga approach provides no guidance on important procedural issues like statutes of limitation, retroactivity, and exhaustion. The uncertainties in the Filartiga process become clear when one compares it to a rare political branch incorporation of international human rights law - the TVPA. The TVPA defined the new federal causes of action for torture and extrajudicial killing with a careful precision that contrasts with the vague contours of analogous CIL and Torture Convention prohibitions. $^{251}$ It provided a statute of limitations designed to

249. See supra text accompanying note 95.

250. See supra text accompanying notes 134-36.

251. The TVPA's definitions of torture and extrajudicial killing are narrower than those definitions under CIL and the Torture Convention. They track the definitions adopted by the Senate's understanding of the requirements of the Torture Convention, which was a condition to the Senate's consent to ratification of the treaty. See S. REP. No. 102-249, at 6 (1991). 
avoid stale claims 252 and included an exhaustion requirement designed to avoid unnecessary interference with foreign nations and undue burden on U.S. courts. ${ }^{253}$

This latter consideration points to an even more serious concern regarding the foreign relations implications that inhere in a civil human rights suit brought against a foreign governmental official. Such a lawsuit obviously can affect the relations between the nation permitting the lawsuit and the nation whose officials are subject to the lawsuit. This foreign relations concern has led most nations of the world to permit their courts to apply human rights law against foreign government officials only in criminal suits under the control of the executive branch. Both the British and Spanish torture statutes at issue in the Pinochet litigation contain this limitation.

The United States appears to be unique in opening its courts to civil suits by foreign plaintiffs against foreign governmental officials for human rights violations that occurred on foreign soil. ${ }^{254}$ The revival of the long-dormant ATS in a context far removed from its original purposes may not have happened by accident, 255 but it did not come about through a democratic process. Although private suits under the ATS have sometimes met with the approval of the executive branch when the private plaintiffs' interests have coincided with U.S. foreign policy aims, ${ }^{256}$ no mechanism in ATS litigation ensures this overlap. ${ }^{257}$ Instead, private litigants make the decisions regarding when to bring these lawsuits, which countries to

252. See Torture Victim Protection Act, Pub. L. No. 102-256, § 2(c), 106 Stat. 73, 73 (1992) (set forth in statutory note following Alien Tort Statute, 28 U.S.C. $\$ 1350$ (1994)); see also H.R. REP. No. 102-367, at 5 (1991), reprinted in 1992 U.S.C.C.A.N. 84, 88 (statute of limitations requirement "insures that the Federal Courts will not have to hear stale claims").

253. See § 2(b), 106 Stat. at 73; see also H.R. REP. No. 102-367, at 5 (exhaustion requirement "ensures that U.S. courts will not intrude into cases more appropriately handled by courts where the alleged torture or killing occurred" and avoids "exposing U.S. courts to unnecessary burdens").

254. See supra note 145.

255. For a discussion of the role of the Center for Constitutional Rights in the Filartiga case, see STEPHENS \& RATNER, supra note 246, at 9-10.

256. See, e.g., Brief for the United States as Amicus Curiae, Kadic v. Karadzic, 70 F.3d 232 (2d Cir. 1995) (Nos. 94-9035, 94-9069); Amicus Curiae Brief by the United States Departments of Justice and State, Filartiga v. Pena-Irala, 630 F.2d 876 (2d Cir. 1980) (No. 796090), reprinted in 19 I.L.M. 585 (1980). But see Brief for the United States as Amicus Curiae, Trajano v. Marcos, 978 F.2d 493 (9th Cir. July 10, 1989) (No. 86-2448), excerpted in State Territory, Jurisdiction, and Jurisdictional Immunities, 2 CumULATrve Digest 1981-1988 \& 7, at 1571-72 (brief from Reagan administration objecting to the use of the ATS for human rights litigation).

257. In suits against leaders of foreign countries, the Executive does have the ability to stop human rights litigation by suggesting head-of-state immunity, and it has done so in a number of instances. See supra notes 184-87 and accompanying text. Most human rights lawsuits, however, do not implicate head-of-state immunity; in those cases, the Executive is left with, at most, an amicus curiae role. 
target, and what relief to seek. Neither these litigants, nor the judges hearing these cases, possess the expertise and constitutional authority to weigh the benefits of the litigation against its political costs. ${ }^{258}$ Moreover, this litigation is highly decentralized and ad hoc, and it is subject to a variety of procedural restraints that do not apply to the political process.

These features of U.S. civil litigation help explain why the executive branch has sometimes opposed even very limited measures aimed at incorporating international human rights law into such litigation. Thus, for example, the Bush administration initially opposed the TVPA ${ }^{259}$ and the Clinton administration initially opposed the 1996 amendments to the FSIA, ${ }^{260}$ both on the ground that even these limited endorsements of international human rights litigation would, on balance, harm U.S. foreign relations machinery. For a similar reason, President Clinton recently declined to exercise his authority under 1998 Amendments to the FSIA to assist plaintiffs in recovering human rights judgments against Iran and Cuba. ${ }^{261}$ As

258. See generally Jack I. Garvey, Judicial Foreign Policy-Making in International Civil Litigation: Ending the Charade of Separation of Powers, 24 LAw \& PoLY. INTL. Bus. 461 (1993); John Yoo, Federal Courts as Weapons of Foreign Policy: The Case of the HelmsBurton Act, 20 Hastings INTL. \& CoMp. L.R. 747, 772-75 (1997).

259. See Torture Victim Protection Act of 1989: Hearing on S. 1629 and H.R. 1662 Before the Subcomm. on Immigration and Refugee Affairs of the Senate Comm. on the Judiciary, 101st Cong., 2d Sess. 8 (1990) (written and oral testimony by John O. McGinnis, Deputy Assistant Attorney General, Office of Legal Counsel, U.S. Department of Justice and David P. Stewart, Assistant Legal Advisor for Human Rights and Refugee Affairs, U.S. Department of State). President Bush did eventually sign the TVPA legislation. Upon signing it, however, he expressed concern that "U.S. courts may become embroiled in difficult and sensitive disputes in other countries, and possibly ill-founded or politically motivated suits, which have nothing to do with the United States and which offer little prospect of successful recovery" and that "[s]uch potential abuse of this statute undoubtedly would give rise to serious frictions in international relations and would also be a waste of our own limited and already overburdened judicial resources." Statement on Signing the Torture Victim Protection Act of 1991, Mar. 12, 1992, 28 Weekry Comp. Pres. Doc. 465, 466 (Mar. 16, 1992).

260. See The Foreign Sovereign Immunities Act: Hearings Before the Subcomm. on Courts and Admin. Practices of the Senate Comm. on the Judiciary, 103d Cong., 2d Sess. 10 (1994) (statement of Jamison S. Borek, Deputy Legal Advisor to U.S. State Department); The Foreign Sovereign Immunities Act: Hearings Before the Subcomm. On Courts and Admin. Practices of the Senate Comm. on the Judiciary, 103d Cong., 1st Sess. (1994) (statement of Stuart Schifter, Deputy Assistant Attorney General, Civil Division, Department of Justice).

261. In 1998, Congress amended the FSIA to provide for attachment and execution of otherwise-blocked assets and government assistance in locating the assets in suits against state sponsors of terrorism. See Pub. L. No. 105-277, \$117, 112 Stat. 2681, 2681-491 to 2681492 (codified as amended at 28 U.S.C.A. $\$ \$ 1610(\mathrm{f})(1)(\mathrm{A}),(1)(\mathrm{B}),(2)(\mathrm{A}),(2)(\mathrm{B})$ (Supp. 1999)). Subsection (d) of the 1998 amendment permits the President to waive its requirements "in the interest of national security." See $\$ 117$ (d) (codified as amended at statutory note following 28 U.S.C.A. $\$ 1610$ (Supp. 1999)). The President invoked subsection (d) in an attempt to waive application of the 1998 amendment in its entirety. See Memorandum on Blocked Property of Terrorist-List States, Presidential Determination No. 99-1, 34 WEEKLY COMP. Pres. Doc. 2088 (Oct. 21, 1998); see also President's Statement on Signing the Omni- 
these examples illustrate, the incorporation of international human rights law into the U.S. civil litigation system implicates significant foreign relations issues. These issues, as we argued above, are best resolved by the political branches in the first instance.

\section{CONCLUSION}

Pinochet is a significant decision on many levels. Despite the Law Lords' narrowing of the extradition charges against Pinochet, and the fact that Pinochet might well never stand trial in Spain, the decision is a major victory for the idea that international law can regulate domestic human rights abuses. More broadly, the decision has sparked important debates over the legitimacy and efficacy of unilateral assertions of universal jurisdiction, the relationship between the exercise of this jurisdiction and political solutions (like amnesties) in the state where the bulk of the human rights abuses occur, and the virtues and vices of an international criminal court to try human rights abuses. 262

Pinochet also is significant because it shows that international law and the mechanisms of its enforcement are changing. Recent developments in international law, especially in the areas of human rights and criminal law, have placed substantial pressure on traditional notions of sovereignty, including notions of sovereign immunity. Concepts such as universal jurisdiction have increased the potential enforceability of international law in domestic legal systems. As a result, domestic courts will increasingly face criminal and civil cases concerning alleged violations of international law. The United States already has experienced this phenomenon, with its growing number of civil lawsuits challenging abusive practices around the world.

This increased relevance of international law to domestic litigation has the potential to enhance the rule of law in the international community. It also means, however, that the enforcement of international law will increasingly implicate - and sometimes be in tension with - domestic constitutional standards. We have argued that, in the United States, the vagueness of international human

bus Consolidated and Emergency Supplemental Appropriations Act, 1999, 34 WEEKLY COMP. Pres. Doc. 2108 (Oct. 23, 1998). The single court to consider the issue has ruled that the President's waiver exceeded his authority under the 1998 amendment. See Alejandre v. Republic of Cuba, 42 F. Supp. 2d 1317, 1331-32, 1339 (S.D. Fla. 1999), rev'd on other grounds, 1999 U.S. App. LEXIS 18841 (11th Cir. Aug. 11, 1999).

262. For a particularly thoughtful essay on these issues in light of the House of Lords' first Pinochet decision, see Paul W. Kahn, On Pinochet, 24 Boston Review, Feb./March 1999 , at 18. 
rights law and the foreign policy implications of human rights litigation justify restrictions on the incorporation of international human rights law into the domestic civil litigation system. In addition, we have claimed that, for reasons of separation of powers and federalism, federal courts should not play an independent role in incorporating international human rights law into the U.S. legal system but should instead await authorization and direction from the federal political branches. The Pinochet decision reduces some of the barriers to the enforcement of international human rights law, at least in criminal prosecutions of former heads of state. The decision also provides support, however, for the limited and politically controlled approach to civil human rights litigation that we have suggested. 